Jazmin P. Scarlett ${ }^{1,2^{*}} ;$ Felix Riede $^{2}$

\title{
The Dark Geo-Cultural Heritage of Volcanoes: Combining Cul tural and Geoheritage Perspectives for Mutual Benefit
}

${ }^{1}$ School of Environmental Sciences, University of Hull, Cottingham Road, HU6 7RX, UK

${ }^{2}$ Laboratory for Past Disaster Science (LAPADIS), Department of Archaeology and Heritage Studies, Aarhus University, Moesgard Allé, 8270 Højbjerg, Denmark

*corresponding author: j.scarlett@2014.hull.ac.uk

ORCID number: 0000-0003-2745-8452

\section{Acknowledgements}

Jazmin Scarlett was generously supported by the Aarhus University Research Foundation Visiting Grant and the Laboratory for Past Disaster Science within the Department of Archaeology and Heritage Studies at Aarhus University. Felix Riede is generously supported by the Independent Research Fund Denmark grant 6107 00059B.

\begin{abstract}
It is now widely accepted that vulnerability is in part culturally and historically contingent. Similarly, geoheritage cannot be readily disentangled from cultural values and cultural heritage given that the assignment of value to a given geosite is conducted in the present and that many if not most geosites are also sites of culture-historical significance. Vice versa, most tangible cultural heritage also contains elements of geoheritage. To bridge these perspectives, we propose the notion of geo-cultural heritage; we argue that the viewpoints of geoheritage and of cultural heritage - here especially of dark heritage - can be brought together for mutual benefit. We begin by demonstrating through a bibliometric analysis that the two fields never were fully connected and that they remain disjointed. We highlight at the same time that cultural heritage generally leverages more public attention while the natural sciences arguably command greater attention with policymakers. We then illustrate how geoheritage and dark cultural heritage can be brought together through four case studies of past volcanism and their complex human impacts. In concluding, we encourage heritage workers to be more fully interdisciplinary, to read more widely outside their own fields, and to disseminate their research more broadly for mutual benefits of preservation, risk reduction and valorisation.
\end{abstract}




\section{Keywords}

geoheritage; cultural heritage; dark heritage; geotourism; dark tourism; social volcanology

\section{Introduction}

Geoheritage focuses on the diversity of minerals, rocks and fossils, as well as geomorphological features that illustrate the effects of present and past climate and environmental change (McBriar, 1995). The attribution of value to these geological features is based on the argument that they both constitute resources for science, education and tourism, and that they provide a sense of place tied to historical, cultural, aesthetic and religious values (Brocx and Semeniuk, 2007; Brocx, 2007). Related concepts such as geoconservation and geotourism extend the scope to the preservation of specific landforms (Wyatt and Moss, 1990; Blandin, 1992; Gibson et al., 1994; Withers and Horwitz, 1996) and the enhancement and use of a given geosite in touristic marketing (Stueve et al., 2002). Importantly, geotourism also aims to raise awareness of the importance of geoheritage officially recognised or not - and the dissemination of earth science knowledge (Dávid, 2004). A geotourist, it is argued, travels to gain increased awareness and knowledge of a given geosite or landform, learning about their natural characteristics and relations to human history, commerce, arts or crafts (Stueve et al., 2002).

What should be evident from this brief sketch of geoheritage and related disciplinary fields is that they cannot readily be disconnected from cultural heritage because (a) the framing and valorisation of a given geosite is conducted within a specific contemporary cultural setting, and (b) the bulk of all recognised geosites directly relate to aspects of cultural heritage - even a cursory view at key publications such as the journal Geoheritage will illustrate as much. In this paper, we attempt to build bridges between the fields of geoheritage and cultural heritage. We see this as a pressing matter not just because both areas stand to make significant intellectual and practical gains from greater integration, but because thinking geological and cultural heritage together - we here propose the term geo-cultural heritage - articulates particularly well with research on natural hazards and risk reduction. It has long been pointed out that the impact of natural hazards are not in any straightforward nor natural, but emerge in the interaction of a given hazard with at-risk communities (O'Keefe et al., 1976). Indeed, it is now widely accepted that vulnerability emerges within the context of a community's history (GarcíaAcosta, 2002; Bankoff, 2004), and that risk perception is largely culturally contingent. Hence, risk reduction also must be culturally sensitive (Mercer et al., 2012). By this token, the emerging field of geoethics also 
becomes relevant here as it is concerned with reflections on the values, appropriate behaviours and practices where human activities intersect the geosphere (IAPG, 2012; Peppoloni and Di Capua, 2012).

Our focus here is on volcanism and its coupled geological and cultural heritage (Németh et al., 2017). Approaches that tackle contemporary volcanism and its impact on human communities in culturally embedded ways has been termed 'social volcanology' (Donovan, 2010). Past volcanism has repeatedly affected human communities; the historical and archaeological remains of these interactions - the geological and cultural heritage - furnish the basis for a 'paleo-social volcanology' (Riede, 2018) that deploys such culturally specific and often highly valued heritage components in risk communication, education and debate (cf. Parkash, 2012; Neuberg, 2014; De Lucia, 2014; Riede et al., 2016).

Volcanoes have provided human societies with a great number of benefits in terms of ready building materials and geothermal energy (Arnórsson et al., 2015; Dehn and McNutt, 2015) as well as through soil improvement (Ugolini and Zasoski, 1979; James et al., 2000; Delmelle et al., 2015). Yet, volcanoes are also firmly associated with the awesome spectacles of their eruptions and the usually detrimental impacts these have on human communities. The trope of the destructive volcano is particularly strong in popular imagination (Pomeroy, 2008; Kozák and Cermák, 2010; Pyle, 2017). The study of such calamities and their tangible and intangible legacies has been termed 'dark heritage', and its use in tourism 'dark tourism' (Hooper and Lennon, 2017). While dark heritage and dark tourism focus on those aspects of history which are problematic, unwanted or unsavoury classic examples of such sites are political prisons such as Alcatraz, Robben Island (Strange and Kempa, 2003) or Long Kesh (McAtackney, 2013), concentration camps and other war sites (Thomas et al., 2016) or gruesome murders (Foley and Lennon, 1996) - they inadvertently exert a substantial pull on visitors (Kulcsar and Simon, 2015). Importantly, cultural heritage practitioners have long since demonstrated that natural and cultural heritage are inseparable (e.g. Lowenthal, 2005) and that the valorisation of any given heritage feature is dynamic and often contested.

Cognisant of the significant entanglements of natural/geological and cultural heritage, we here propose the notion of geo-cultural heritage. We argue that the viewpoints of geoheritage and of cultural heritage - here especially of dark heritage - can be brought together for mutual benefit. Initial attempts of bringing these perspectives together have emerged in the literature (Erfurt-Cooper et al., 2015), but we demonstrate through a 
bibliometric analysis that the two fields remain largely disjointed. At the same time, we highlight the maturity of cultural heritage research and the pattern evident in site visitors that cultural rather than geological heritage generally leverages more public attention while acknowledging that the natural sciences command more policymaker attention. We illustrate how geoheritage and dark cultural heritage can be brought together through four case studies of past volcanism and their complex human entanglements. In concluding, we encourage heritage workers to be more fully interdisciplinary, to read more widely outside their own fields, and to disseminate their research more broadly for mutual benefits of preservation, risk reduction and valorisation.

\section{Materials and Methods}

In order to assess the current relations between the disciplinary fields of geoheritage, cultural heritage, geoconservation, geotourism, geoethics, dark tourism, and dark heritage, we have systematically collected key texts and interrogated their citation relations as a way of understanding whether and to what degree they overlap and interact. We subject these texts to a bibliometric citation analysis and visualise the results using network algorithms. In this way, we track patterns of knowledge production, use and the development of these disciplines in an evidence-based fashion (Hull, 1988; Hoffmann and Doucette, 2012). Previously, citation analysis has been used as a method of assessing research impact of individual publications (Nicolaisen, 2007; Sarli et al., 2010); for gauging the extent of a given publication's influence on the literature; for tracking the advancement of knowledge with the inherent assumption that significant publications will demonstrate a high citation count (Wade, 1975; Lawani, 1977; Kostoff, 1998); to detect scientific collaboration; and to map knowledge transfer across domains (Ding et al., 2014).

Citation analysis is an integral component of journal ranking criteria, and is best known as a tool to assess the impact of individual researchers and their institutions (Nightingale and Marshall, 2013). It has been shown that higher citation rates are due to articles (1) being written in English; (2) addressing generalist areas rather than specific disciplines; (3) providing reviews rather than original research; (4) representing cutting-edge research; (5) being longer rather than shorter; (6) addressing established rather than emerging disciplines; (7) appearing in ISI-indexed journals (Seglen, 1997); (8) pertaining to methodology; and lastly (9) by being jointly authored by international teams (Whitehouse, 2001). To measure an individual researcher's impact the h-index is used. This index calculates the highest number of articles published by the author that have the equivalent number of citations or above (Nightingale and Marshall, 2013). An h-index of three, for instance, shows that the author has 
published three articles with a minimum of three citations each. This arguably enables citation performance and productivity to be compared and reduces the influence of few but highly cited articles (Nightingale and Marshall, 2013).

To investigate citations in the seven disciplinary fields in focus here, we initially employed the Publish or Perish software (Harzing, 2007). The program was developed to mine academic citations from a variety of online databases on the basis of the parameters chosen by the analyst, and to then provide the following metrics:

- total number of papers and total number of citations

- average citations per paper, citations per author, papers per author, and citations per year

- number of authors per paper

- $\quad$-index

- $\quad$-index

- contemporary h-index

The g-index aims to improve on the h-index by giving more weight to highly cited articles (Egghe, 2006), whilst the contemporary h-index aims to improve the original h-index by giving weight to more recent articles, thus rewarding academics who maintain a steady level of activity (Sidiropoulos et al., 2006). Note that due to the limitations inherent in the program, publications not written in English were excluded. Secondly, publications with no citations were also excluded - these are, at any rate, unlikely to have had a lasting impact on the disciplines in focus here.

Originally, citation data were harvested from three separate sources - Google Scholar ${ }^{\odot}$, Microsoft Academic $^{\odot}$ and CrossRef ${ }^{\odot}-$ but results were identical; subsequently, only Google Scholar ${ }^{\odot}$ was used. Data in the following categories were recorded: a general search for all published material within the seven disciplinary fields; the total years of active publishing in each disciplinary field; the ten mostly highly cited papers in each disciplinary field; the ten most prolific authors based on the number of publications; the ten most common journal destinations where research in the seven disciplinary fields has been published; forward citation journal destinations for the ten most highly cited papers and lastly; author overlap between disciplinary fields. Once tabulated, patterns in these data are visualised using network analysis. Networks are efficient and elegant means 
of visualising relations among the nodes - here individual papers, journals and disciplinary fields - and are regularly used to interrogate the historical developments of scientific research fields (Fanelli and Glänzel, 2013; Chappin and Ligtvoet, 2014; Radev et al., 2015). Several software solutions are available (for instance, http://www.vosviewer.com/ or Sci2 - see Lewis and Alpi, 2017). Here, we employ the open-source gephi suite (https://gephi.org/ - see Bastian et al., 2009).

\section{Results}

Table 1 summarizes the bibliometric findings of this citation analytical exercise. Several striking differences are extant between the disciplinary fields investigated. First, research within the domain of cultural heritage has been conducted the longest. This has unsurprisingly resulted in the highest total number of citations, although, interestingly, not in the highest total number of papers published overall. The definition of a specific geological heritage field and its derivatives geoconservation and geotourism occurred much later. At the same time, it appears that citation rates - both annually and annually by author - are considerably higher in the geological branch of the heritage domain indicating a rapid development and a high publication rate.

Table 1 Summary of the citation analysis exercise for cultural heritage, dark heritage, dark tourism, geoheritage, geotourism, geoconservation, and geoethics. The overarching disciplinary fields of cultural and geological heritage are shaded in grey, but note that the term geotouris $m$ actually appears in the literature prior to the appearance of the term geoheritage.

\begin{tabular}{|c|c|c|c|c|c|c|c|c|c|}
\hline Disciplinary field & 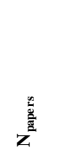 & 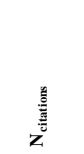 & 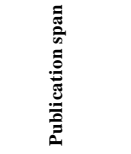 & 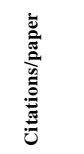 & 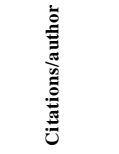 & 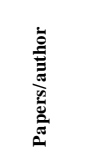 & 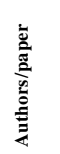 & & 总 \\
\hline Cultural heritage & 287 & 28552 & 1958-2016 & 99.48 & 18929.82 & 195.39 & 2.02 & 92 & 146 \\
\hline Dark heritage & 83 & 5450 & 1981-2017 & 65.66 & 3719.99 & 62.5 & 1.58 & 20 & 73 \\
\hline Dark tourism & 531 & 13039 & $1995-2018$ & 24.56 & 9836.72 & 419.92 & 1.53 & 52 & 102 \\
\hline Geoheritage & 385 & 2731 & 1993-2018 & 7.09 & 1591.27 & 214.32 & 2.53 & 23 & 37 \\
\hline Geoconservation & 283 & 3957 & 1993-2017 & 13.98 & 3097.47 & 195.87 & 2.07 & 26 & 55 \\
\hline Geotourism & 599 & 5946 & $1986-2018$ & 9.93 & 3992.08 & 382.79 & 2.15 & 34 & 59 \\
\hline Geoethics & 115 & 659 & $1996-2018$ & 5.73 & 400.26 & 76.84 & 2.03 & 13 & 19 \\
\hline
\end{tabular}


The ten most productive authors per field (Table 2) prove interesting, as the results do not directly correspond to the most impactful paper as listed in Table 3. As is evident, several authors appear multiple times with different highly-cited papers and some authors feature in multiple disciplinary field lists, albeit not across the divide between cultural and geological heritage domains. This overlap between author productivity rankings and the rankings of impactful publications hints at there being generally substantial overlap within the cultural and geological heritage domains, but little to no overlap between them.

Table 2 Summary of the ten most prolific authors based on the number of publications that have received citations for cultural heritage, dark heritage, dark tourism, geoheritage, geoconservation, geotourism and geoethics. $\mathrm{N}_{\text {papers }}$ includes first- or sole-author publications as well as co-authored ones.

\begin{tabular}{|c|c|c|}
\hline Disciplinary field & Author & $\mathbf{N}_{\text {papers }}$ \\
\hline \multirow[t]{10}{*}{ Cultural heritage } & Remondino F. & 168 \\
\hline & Lourenco P.B. & 113 \\
\hline & Bagilioni P. & 101 \\
\hline & Hyvonen E. & 90 \\
\hline & Timothy D.J. & 87 \\
\hline & Sabbioni C. & 76 \\
\hline & Ikeuchi K. & 72 \\
\hline & Guidi G. & 70 \\
\hline & Jokilehto J. & 55 \\
\hline & Prott L.V. & 53 \\
\hline \multirow[t]{3}{*}{ Dark heritage } & Biran A. & 7 \\
\hline & McAtackney L. & 6 \\
\hline & Poria Y. & 5 \\
\hline
\end{tabular}




\begin{tabular}{|c|c|c|}
\hline & $\begin{array}{l}\text { Carr G. } \\
\text { Hartmann R. }\end{array}$ & 3 \\
\hline Dark tourism & $\begin{array}{l}\text { Stone P. } \\
\text { Korstanje M. } \\
\text { Sharpley R. } \\
\text { Foley M. } \\
\text { Lennon J.J. } \\
\text { Isaac R. } \\
\text { Boyd S. } \\
\text { Timothy D.J. } \\
\text { Ashworth G. } \\
\text { Dann G. }\end{array}$ & $\begin{array}{l}52 \\
33 \\
27 \\
25 \\
20 \\
15 \\
13 \\
13 \\
13\end{array}$ \\
\hline Geoheritage & $\begin{array}{l}\text { Brilhá J. } \\
\text { Reynard E. } \\
\text { Semeniuk V. } \\
\text { Komoo I. } \\
\text { Németh K. } \\
\text { Pelfini M. } \\
\text { Hose T.A. } \\
\text { Dowling R.K. } \\
\text { Brocx M. } \\
\text { Migon P. }\end{array}$ & $\begin{array}{l}0 \\
33 \\
32 \\
28 \\
23 \\
23 \\
23 \\
22 \\
21 \\
20\end{array}$ \\
\hline Geoconservation & $\begin{array}{l}\text { Brilhá J. } \\
\text { Sharples C. } \\
\text { Pereira D. } \\
\text { Henriques M. } \\
\text { Ruban D.A. } \\
\text { Hose T.A. } \\
\text { Alexandrowicz Z. } \\
\text { Markovic S. }\end{array}$ & $\begin{array}{l}61 \\
38 \\
34 \\
30 \\
27 \\
26 \\
22\end{array}$ \\
\hline
\end{tabular}




\begin{tabular}{l|l|r}
\hline Geotourism & Hose T.A. & 46
\end{tabular}

\begin{tabular}{l|l|l}
\hline Geoethics & Peppoloni S. & 30
\end{tabular}

Di Capua G.

Bernardo M.

Table 3 Summary of the ten most impactful publications based on the number of citations for cultural heritage, dark heritage, dark tourism, geoheritage, geoconservation, geotourism and geoethics.

\section{Disciplinary Author and Year}

\section{field}


Feilden B.M. and Jokilehto J. (1993) - Book

Smith L. (2004) - Book

Dann G.M.S. and Seaton A.V. (2001) - Int. J. of Hospitality and Tourism

Administration

Hartmann R. (2014) - Journal of Heritage Tourism

Seaton A.V. (2001) - Int. J. of Hospitality and Tourism Administration

Graham B. and McDowell S. (2007) - Cultural Geographies 32

McAtackney L. (2014) - Book

O’Ballance E. (1981) - Book

Van der Merwe C.D. (2014) - Bulletin of Geography: Socio-economic Series

Frew E.A. (2012) - International Journal of Heritage Studies

Henderson J.C. (2007) - Journal of Heritage Tourism 
Strange C. and Kempa M. (2003) - Annals of Tourism Research 366

Sharpley R. and Stone P. (2009) - Book

Foley M. and Lennon J.J. (1996) - International Journal of Heritage Studies

Dann G.M.S. and Seaton A.V. (2001) - Int. J. of Hospitality and Tourism

Administration

\begin{tabular}{|c|c|c|}
\hline \multirow[t]{11}{*}{ Geoheritage } & Reynard E. (2008) - Geogr. Fis. Dinam. Quat. & 85 \\
\hline & dos Reis R.P. and Henriques M.H. (2009) - Geoheritage & 81 \\
\hline & Panizza M. (2009) - Geoheritage & 80 \\
\hline & Brocx M. and Semeniuk V. (2007) - Journal of the Royal Society of Western & 79 \\
\hline & Australia & \\
\hline & de Lima F.F. et al. (2010) - Geoheritage & 65 \\
\hline & Fassoulas C. et al. (2012) - Geoheritage & 62 \\
\hline & Carcavilla L. et al. (2009) - Geoheritage & 61 \\
\hline & Zhao T. and Zhao X. (2009) - Acta Geoscientica Sinica & 57 \\
\hline & Wimbledon W.A.P. and Smith-Meyer S. (2012) - Book & 56 \\
\hline & Gordon J.E. (2012) - Geoheritage & 53 \\
\hline \multirow[t]{11}{*}{ Geoconservation } & Gray M. (2004) - Book & 921 \\
\hline & Sharples C. (2002) - Tasmanian Parks and Wildlife Service & 192 \\
\hline & Henriques M.H. et al. (2011) - Geoheritage & 126 \\
\hline & Brilhá J. (2002) - Environmental Conservation & 104 \\
\hline & Burek C.V. and Prosser C.D. (2008) - Book & 92 \\
\hline & Sharples C. (1993) - Book & 90 \\
\hline & Prosser C.D. et al. (2011) - Book & 88 \\
\hline & Gray M. (2005) - The George Wright Forum & 81 \\
\hline & Brocx M. and Semeniuk V. (2007) - Journal of the Royal Society of Western & 79 \\
\hline & Australia & \\
\hline & Sharples C. (1995) - Tasforests & 78 \\
\hline Geotourism & Dowling R.K. and Newsome D. (2006) - Book & 251 \\
\hline
\end{tabular}


Newsome D. and Dowling R.K. - Book

Zouros N. and McKeever P. (2004) - Episodes

Farsani N.T. et al. (2011) - International Journal of Tourism Research

Buckley R. (2003) - Journal of Ecotourism

Hose T.A. (2008) - Geological Society Special Publications $\quad 118$

Dowling R.K. and Newsome D. (2010) - Book 117

Dowling R.K. (2014) - Book 113

\begin{tabular}{lr}
\hline Peoethics & 37 \\
Cutchin M.P. (2002) - Progress in Human Geography & 37 \\
Stoddard E.W. and Cornwell G.H. (2003) - Liberal Education & 36 \\
Peppoloni S. and Di Capua G. (2015) - Book & 27 \\
Martínez-Frías J. et al. (2011) - Episodes & 24 \\
Cornwell G.H. and Stoddard E.W. (2006) - Liberal Education & 24 \\
Matteucci R. et al. (2014) - Episodes & 22 \\
Matteucci R. et al. (2012) - Annals of Geophysics & 20 \\
Wyss M. and Peppoloni S. (2014) - Book & 19 \\
Peppoloni S. and Di Capua G. (2012b) - Annals of Geophysics & 16
\end{tabular}

It is noteworthy that the number of citations dramatically decreases past the first one or two top citations within most disciplinary fields. There is also a variance in the publication method: whilst the majority are within established journals - which, however, do not necessarily have a high impact factor and many may have limited accessibility - many key texts also are found within edited volumes or in monograph format. There is a general difference between the natural science and social sciences/humanities in terms of publication in journal vs book formats. This may at least partially explain the different speeds of publication within the fields examined here. Journal publication offers a more rapid turn-over as well as a much higher volume of individual publication in relation to the total amount of text produced. 
Exploring the structure of the citation network between authors and research field (Fig. 1) visualises the lack of connectivity between geoheritage and cultural heritage. As expected, geoheritage, geotourism and geoconservation are greatly interconnected, and loosely connect with geoethics. Despite dark heritage being established longer, dark tourism has more published papers and citations, hence the larger circle. Only M. Shackley connects dark tourism and cultural heritage, having published one paper linking the two (Shackley, 2001).

Fig. 1 Citation network of authors publishing in the seven disciplinary fields investigated. The green circles represent the different research fields where the size of the circle represents frequency of publications in the field. $\mathrm{CH}=$ cultural heritage, $\mathrm{DH}=$ dark heritage, $\mathrm{GT}=$ geotourism, $\mathrm{GH}=$ geoheritage, $\mathrm{GC}=$ geoconservation, DT = dark tourism, GE = geoethics. Red circles are individual authors' publications with citations.

Although there appears to be little overlap between authors across the cultural and geological heritage divide, there is substantially more contact when considering the destination journals chosen by these authors (Table 4). The network between destination journals and disciplinary field paints a more complex picture (Fig. 2). Again, we see similar closeness of geotourism, geoheritage, geoconservation and geoethics when compared to dark tourism and dark heritage. Yet, a handful of journals offer the opportunity of cross-linkage: The Tourism Management journal, Journal of Heritage Studies and the International Journal of Heritage Studies link cultural heritage to dark heritage and dark tourism, whilst the Journal of Tourism Studies and Landscape Research connects cultural heritage to geotourism. Interestingly, the International Journal of Tourism Research links cultural heritage with dark tourism, geotourism and geoethics.

Table 4 Summary of the ten most favoured journal destinations based on the number of papers for cultural heritage, dark heritage, dark tourism, geoheritage, geotourism, geoconservation and geoethics.

\begin{tabular}{llc} 
Disciplinary field & Journal & $\mathbf{N}_{\text {papers }}$ with forward citations \\
\hline Cultural heritage & Journal of Cultural Heritage & 130 \\
& & 96
\end{tabular}


Conservation and Management of Archaeological Sites

Annals of Tourism Research

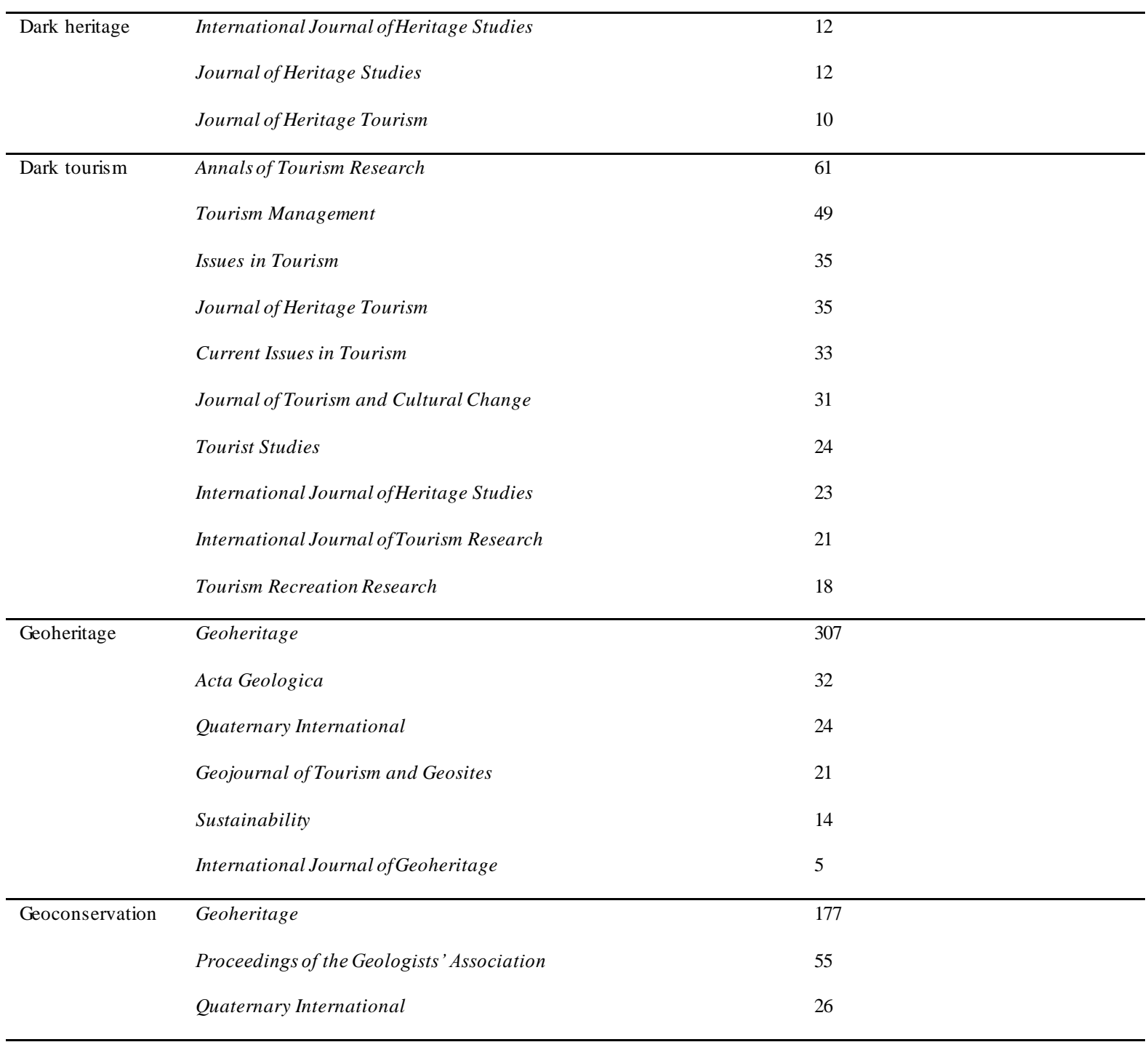




\begin{tabular}{ll}
\hline Geotourism & 204 \\
Geoheritage & 167 \\
Geological Society & 120 \\
Journal of Tourism & 41 \\
Geojournal of Tourism and Geosites & 31 \\
Acta Geoturistica & 24 \\
Acta Geographica & 22 \\
Quaternary International & 20 \\
Journal of Ecotourism & 15 \\
Tourism Management Perspectives & 12 \\
Annalsof Geophysics & 26 \\
Geological Society & 18 \\
Engineering Geologyfor Societyand Territory & 7 \\
Geoethics: ethical challenges(book) & 6 \\
Episodes & 6 \\
EGU General Assembly & 6
\end{tabular}

Fig. 2 Citation network of journals and the seven research fields investigated. The green circles represent the different research fields, the size of the circles represents frequency of publications in the field. $\mathrm{CH}=$ cultural heritage, $\mathrm{DH}=$ dark heritage, $\mathrm{GT}=$ geotourism, $\mathrm{GH}=$ geoheritage, $\mathrm{GC}=$ geoconservation, $\mathrm{DT}=$ dark tourism, $\mathrm{GE}=$ geoethics. Red circles are individual journals.

Again, it is evident that the choices made by authors active within the respective fields are rather limited. Furthermore, the range of chosen journal destinations is more exclusive within some of the fields investigated: dark heritage and geoconservation research appears in only three journals respectively (International Journal of Heritage Studies; Journal of Heritage Studies; Journal of Heritage Tourism Geoheritage; Proceedings of the Geologists' Association and Quaternary International), geoheritage typically appears in five journals (Acta Geologica; Quaternary International; Geojournal of Tourism and Geosites; Sustainability and International Journal of Geoheritage) besides Geoheritage, whilst geoethics work appears in four journals (Annals of Geophysics; Geological Society; Engineering Geology for Society and Territory; Episodes) and as abstracts as 
part of the EGU General Assembly. This trend continues in forward citations: Cultural heritage destinations include cultural/heritage, environmental and economics; dark heritage also is found within cultural/heritage journals but also in geography-related journals. Both geotourism and geoheritage forward citation destinations are within geography and geology journals. Geoconservation is also targeted at geography and geology destinations, as well as ecology and conservation. Lastly, dark tourism research is targeted at heritage and general humanities journals. One interesting and surprising finding is, however, that each field (except for geoethics) has forward citation destinations in tourism-related journals.

\section{Discussion}

The results of our bibliometric analysis and visualisation show that the broad disciplinary fields of cultural and geological heritage are largely disconnected. A lack of citation across the se disciplinary domains and their subfields indicates that there is little shared literature and likely little common ground in terms of terminology, theory and method. Importantly, the field of cultural heritage has the longest research and publication pedigree, and cultural heritage figures prominently in the funding programs of major agencies (e.g. the EU's Horizon2020). Furthermore, the statistics available for many countries indicate that museums of cultural history are among the major attractions for tourists and locals alike (http://www.egmus.eu/). Museums are increasingly active in relation to questions of sustainability, biodiversity and climate change (Cameron and Neilson, 2015; Rees, 2017), although museums of cultural history have not yet fully grasped that chance (Jackson et al., 2017; Jackson et al., 2018), despite the fact that the entanglement of our knowledge about past environmental change and hazards in relation to culture history can be said to afford not only learning opportunities (Riede et al., 2016b) but also certain ethical obligations (Riede et al., 2016a). Aligning geoheritage closer with cultural heritage would open this remarkable public interface to the concerns of geoconservation, sustainability and vulnerability. At the same time, it has been shown repeatedly that the humanities and social sciences remain side-lined in major efforts such as the Intergovernmental Panel on Climate Change's (IPCC) reports (Hulme, 2011; Corbera et al., 2016). A closer alliance between cultural and geological heritage practitioners could thus not only increase public but also policy-maker impact.

Mindful of these results and in an effort to support our argument that investigations of volcanic geoheritage and geoheritage in general - can draw benefits from joint attention from both geoheritage and cultural heritage 
perspectives, we now briefly illustrate how such a geo-cultural heritage perspective could take form. We focus on four volcanic eruption/landforms (Soufrière Hills Volcano, La Soufrière, Vesuvius and the Laacher See) in order to show how both active and dormant volcanoes and their different cultural and geological heritage components can be brought into play. In this effort, we focus specifically on aspects of dark heritage, i.e. aspects of these geosites that place themselves in the "tense intermediary zone between voyeurism and social justice" (Robb, 2009: 58)

\section{Soufrière Hills Volcano, Montserrat}

Soufrière Hills Volcano, on the Lesser Antilles island of Montserrat has been periodically erupting since 1995 (Sword-Daniels et al., 2014), and with geological evidence that similar activity occurred just before first European settlements in 1632 (Smith et al., 2007). Archaeological evidence shows that there were Saladoid (Amerindian) coastal sites (Reid, 2009) (an indigenous cultural group that inhabited Venezuela and the Caribbean from 500 BCE to 545 CE) and pre-Arawak occupation between 4000-2500 BP (Cherry et al., 2012). In the Lesser Antilles, the Arawak were then displaced by the Kalinago, who also inhabited Montserrat (Lalubie, 2013) from approximately 1200 CE. It is unknown what became of the Kalinago, and it was not until 1632 , that the first Irish Catholic settlers colonised the island, to escape Protestant intolerance at the neighbouring island of St. Kitts and, later, from Virginia (Russell, 2015). It is contested whether they brought with them the law of the Kingdom of Ireland, which differed from the Kingdom of England law (Roberts-Wray, 1966). After the English seized Montserrat in 1667, Irish indentured servants and African slaves were imported, displacing small holding Irish farms and replacing them with larger plantations (Russell, 2015). The most curious cultural heritage aspect of the island may be St. Patrick's Day, which embraces the Irish-African creole society. Whilst it was originally celebrated by the Irish, a failed slave revolt took place on the $17^{\text {th }}$ March 1768 (Fergus, 1996), and for future generations captivated the imaginations of the creole society to the point that the failed rebellion was incorporated into the festivities, which attracts tourists the world over (see:

https://www.irishcentral.com/roots/montserrat-irish-st-patricks-day). Through the continued development of the creole society, the festival's meaning has changed throughout the island's colonial history: from postcolonialism, left-wing politics, the Black Power movement, the role of the Roman Catholic church, and since the eruption of 1995, altered spatial dimensions of the festival's home and as a gathering-point of the diaspora that were displaced by Soufrière Hills (McAtackney et al., 2014). 
The volcanic island's most prominent development issue has been the abandonment, following the 1995 eruption, of over 50 settlements in the south of the island, where a permanent exclusion zone of Soufrière Hills Volcano is in effect (Fig. 3).

Fig.3 Aerial photograph of Plymouth and the surrounding area buried by the $25^{\text {th }}$ June 1997 pyroclastic density currents. By Lally Brown, June 1997.

Consequently, development is currently restricted to the north of the island, where new settlements are slowly being developed, and as of last year tour guides have been training for accompanied tours of the outskirts of Plymouth (Skinner, 2018). The inhabitants of Montserrat are on their way to exploiting its dark tourism related to past human impacts and contemporary risks. The Soufrière Hills eruptions are well-investigated volcanologically and the remains from its most recent eruptions offer touristic and research opportunities today. Yet, they also reflect a more troublesome legacy of colonial rule (e.g. Charvériat, 2000; Spence et al., 2007; Kelman and Mather, 2008; Donovan et al., 2014; Barclay et al., 2015).

The recent history of the island epitomises issues of colonial rule and how contemporary world systems fell into place. It is a history of marginalised groups (e.g. Mlambo, 2006; McGrattan, 2010; Montero, 2011; Boyle, 2011) and a history that can be linked to issues of social justice (Wolf, 1990) and of contemporary environmental concerns (Lewis and Maslin, 2015). The destruction of the capital Plymouth is akin to the destruction of St. Pierre, Martinique by Mont Pelée in 1902 (Fig. 4), which had far-reaching effects in terms of early disaster medialisation (Kverndokk, 2015). St. Pierre has been nicknamed the "Pompeii of the Caribbean" (Janssens and O'Keefe, 2010) and Plymouth, too, has been described as: a "modern-day Pompeii in the Caribbean” (Bachelor, 2014). But the trope of Pompeii is itself contested and some Eurocentric short-hand for a moment frozen in time (Holmberg, 2013). Both capitals are dark heritage sites, due to the large cultural, socioeconomic, and political sites also being sites of human trauma and the destruction of the built environment, that almost mirror the settlements destroyed by the $79 \mathrm{CE}$ eruption of Vesuvius, in that pyroclastic density currents essentially buried the surrounding landscape. Visiting these deserted places is very much dark tourism for those from the outside, while the land is being reclaimed in an ad hoc fashion by those who in fact live there (Skinner, 2018). Both places carry an inheritance of loss, to use Holmberg's (2013) term. With due tact, respect and professional conduct, this inheritance - this geo-cultural heritage - could be turned into powerful generators of income and 
insight. Here, the community archaeology approach - a branch of archaeology concerned with inclusion, participation, education and interaction rather than a one-way conferral of knowledge (Ryzewski and Cherry, 2012) - could leverage cultural heritage to focus also on the intimately related topics of social justice and vulnerability.

Fig. 4 (A) Photograph of abandoned Plymouth, and (B) the rebuilt Statue of Mary in St. Pierre, Martinique. By (A) Lally Brown, 1996 and (B) D. Morvan, 2006.

\section{La Soufrière, St. Vincent and the Grenadines}

La Soufrière Volcano, on the main island of St. Vincent, is one of the most active volcanoes in the Lesser Antilles Volcanic Arc (Robertson, 1995), last erupting explosively in 1979 and with effusive lava dome growth until 1984 (Robertson, 2005). The small island state shares much history and many contemporary challenges Montserrat and other similar island in the region (Briguglio, 1995). Currently, research draws on the past two eruptions of 1979 and 1902-1903 to educate, to prepare for the future and for capacity building - through an annual volcano awareness week that coincides with the 1979 eruption commemoration where school children and the wider public are imparted knowledge of the volcano in a semi-formal setting (Fig. 5).

Fig. 5 School children learning about volcanoes and La Soufrière during the 2016 Volcano Awareness Week. By Jazmin Scarlett, April 2016.

Besides the physical presence of the active volcano, and extinct volcanic centres forming a central axial range of mountains (Robertson, 2005), various outcrops exist that offer outstanding examples of volcanic island processes. Various popular eco-tourism routes criss-cross the mountain range, rainforests and bays (SVG Tourism Authority, 2009) (Fig. 6) and, Amerindian petroglyphs are present across the island, which are likewise a source of tourism income that have been submitted for consideration as cultural heritage sites (UNESCO, 
2018a) (Fig. 6). It would not only be possible to integrate these routes with a narrative of the geology of the

island but to integrate community-led research into the exploration of these prehistoric landscape features.

Fig. 6 (A) The La Soufrière Nature Trail, and (B) a petroglyph of St. Vincent and the Grenadines. By (A) Jazmin Scarlett, April 2016 and (B) Megan Walker, 2017.

St. Vincent and the Grenadines have a complex colonial history, which has contributed to both ethnic and religious diversity in the present (e.g. Brathwaite, 1971; Bolland, 1998; Shepherd and Richards, 2002; Finneran, 2013). This history has not been a happy one and encapsulates many aspects of the emergence of contemporary world systems as well as the emergence of our contemporary environmental quandaries (Lewis and Maslin, 2015). Yet, the history of slavery and colonialism has been embraced and exploited as a form of dark heritage on other Caribbean islands, in the southern United States and in West Africa (e.g. Dann and Seaton, 2001; Mowatt and Chancellor, 2011; Tunbridge and Ashworth, 2017). Weaving narratives of volcanic unrest and human impact together with narratives of colonialism, resistance, migration, social and environmental justice may yet be for the benefit - also in terms of tourism-generated income - for all involved.

Vesuvius, Italy

The cities of Pompeii and Herculaneum are known the world over and are, in fact, prime examples of dark heritage. Their discovery was integral to the development of rese arch fields such as archaeology, just as research on Vesuvius has been integral in the development of volcanology - so much so that the very term Pompeii has become a common and more often than not misleading idiom for some site - tephra-covered or not - frozen in time (cf. Holmberg, 2013). Pompeii does offer unprecedented insights into the life of the Romans (Beard, 2008) and has long inspired art, theatre and film (Pomeroy, 2008; Sigurdsson, 2015). The volcano looming over the city of Naples and the world famous casts of agonisingly dying animal and human inhabitants of this ancient city adds its element of titillation (Kulcsar and Simon, 2015) together making Pompeii into a tremendously attractive site for visitors (Fig. 7). In 2014, nearly 2.5 million visitors came to Pompeii (Culture, 2014). In 2017, this number has risen to over 3.4 million and many more see the various exhibitions staged about Pompeii in museums around the world (e.g. at the British Museum in 2013, see 
http://www.britishmuseum.org/whats_on/exhibitions/pompeii_and_herculaneum.aspx). In contrast, only about 1

million visitors came to the Vesuvius National Park in 2004 (Erfurt-Cooper, 2010a) and just over 4 million in 2017 (http://www.pompeiisites.org/Sezione.jsp?titolo=Dati+Visitatori\&idSezione=9). While these figures derive from different years, they clearly support and reflect the general trend, already alluded to above, that institutions of cultural heritage such as museums or sites of culture history or art, attract substantially more visitors than their natural history counterparts (Istat, 2016).

Fig.7 (A) A classic image of Vesuvius that forefronts the cultural heritage in the form of Pompeii, deliberately chosen from Wikipedia (Morn the Gorn - Own work, CC BY-SA 3.0, https://commons.wikimedia.org/w/index.php?curid=7919520), and (B) a film poster of one of the many productions of the Last Days of Pompeii, going back to the painting of the same title by Karl Bryullov from 1833.

There is little doubt that much effective outreach about risk, vulnerability and coupled geological and cultural heritage is already going on at Pompeii. It is not, however, strongly visible in the literature and rarely framed as such. Given, however, just how many people - locals and tourists alike - are at risk from renewed eruption at Vesuvius (Zuccaro et al., 2008; Scandone et al., 2015), effective risk communication is a high priority. There is great awareness of this need and ethical obligation to communicate these risks (Solana et al., 2008; De Lucia, 2014) and including elements of cultural framings of risk and response (Everson, 2012; Chester et al., 2015) may assist in these endeavours.

\section{Laacher See, Germany}

The eruption of the Laacher See volcano, part of the Eifel volcanic zone located in present-day Germany, around 12900 years ago was the last major volcanic event in continental Europe, lasting up to several months, it devastated the immediate surroundings (Schmincke et al., 1999; Schmincke, 2006). Its eruption sequence and associated processes such as the formation and subsequent collapse of a dam on the nearby river Rhine are well investigated (Park and Schmincke, 2009). Indeed, recent research motivated by a concern about the eruptions 
impact on human communities at the time has highlighted the extent of the tephra fallout from the eruption (Riede et al., 2011) and the likely impacts of this eruption on animals, plants and people living in Europe at the time (Riede, 2008; Riede, 2016; Riede, 2017a; Riede, 2017b). The Eifel is a recognised UNESCO Geopark (see https://www.geopark-vulkaneifel.de/en/), the Laacher See a beautiful recreational area(Fig. 8), and much vigorous outreach focusing on the regions rich geo-cultural heritage - Roman and Medieval mining, underground beer storage and contemporary industry (Custodis, 1994; Kremer, 1995) - is going on (ErfurtCooper, 2010).

Fig. 8 A drone photo of the Laacher See caldera. By Florian Sauer, May 2018.

We note, however, that much of this outreach circumvents issues of past human impacts (Bitschene and Schüller, 2011; Bitschene, 2015) and hence underutilises the opportunity of putting issues of vulnerability and resilience to debate, and underutilises the touristic appeal of the eruption's dark heritage. While unlikely in the near future, any potential reawakening of this volcano would likely result in major infrastructure costs (Leder $e t$ al., 2017) or even secondary technological disasters with not merely local effects but reverberations across Europe (Fig. 9). Moreover, and perhaps more usefully still, the Laacher See can be used as a case study for seriously thinking through the societal consequences and responses to events of this magnitude and to do so in a manner that is historically informed by what we know of past impacts (Donovan and Oppenheimer, 2016; Riede, 2017a). A strategic and balanced inclusion of the Laacher See's dark heritage would likely further increase the region's and the eruption event's appeal and hence lift the reach of any associated educational initiatives up on a supra-regional scale.

Fig. 9 The location of the Laacher See and proximal $(<50 \mathrm{~km})$, medial $(50-500 \mathrm{~km})$ and distal $(500-1000 \mathrm{~km})$ hazard zones, following Thorarinsson (1979), in relationship to (A) European population density and (B) major power plants.

\section{Conclusion}

Volcanoes and their landforms are natural features but are also commonly deeply entangled with human history, culture and society. Culture history and cultural heritage are a resource on which people anywhere draw for 
identity formation and for social capital. The UN Millennium Ecosystem Assessment (2005), for instance,

Fig. 10 The categories of cultural ecosystem services as defined by the UN Millennium Ecosystem Assessment. After Hølleland et al. (2017).

Cultural ecosystem services were determined to be nonmaterial benefits that people obtain from ecosystems through recreation and aesthetic experiences, spiritual enrichment, reflection and cognitive development. Cultural heritage values are described as “....many societies place high value on the maintenance of either historically important landscapes (cultural landscapes) or culturally significant species"(Millennium Ecosystem Assessment, 2003, pg. 59). From the perspective of volcanology, volcanoes and their associated landforms can almost always be slotted into all ten of the subcategories of cultural services. Assessments of volcanic risk, vulnerability, resilience, and their translations into hazard maps and warning messages all require cultural understanding. Cultural values and perceptions provide saliency to specific hazards through a specific and culturally variable prioritisation of threats (Cutter et al., 2008).

Historical data - geological, archival and archaeological - of past eruptions can be fed into building community resilience through education and knowledge systems, participatory research (for instance, geo-archaeological), a deep sense of place, tourism, spirituality and religion, social relations, aesthetic values, recreation, and ecotourism. Accepting the entanglement of geological and cultural heritage, we have here proposed the notion of geo-cultural heritage and have presented some initial suggestions for how certain aspects of cultural heritage can usefully be blended with aspects of geological heritage. Seen against the background of our citation analysis, we also argue for increased interdisciplinarity. Cultural heritage professionals have developed countless ways of engaging local communities in the context of, for instance, community archaeology projects (Moshenska and Dhanjal, 2011; Moshenska et al., 2011;Fernández et al., 2017). Cultural heritage sites almost 
universally tell stories of past human-environment relations (Rockman, 2015; Hambrecht and Rockman, 2017) and from here it is but a small step to thinking volcanic hazards together with cultural heritage and cultural history - a trend that is in fact already on-going (Cronin and Cashman, 2007; Cashman and Cronin, 2008; Cashman and Giordano, 2008; Németh and Cronin, 2009).

Millions of visitors are attracted by the wonders of volcanoes and volcanic landforms every year (Erfurt-Cooper and Cooper, 2010; Erfurt-Cooper et al., 2015; Jones and Ohsawa, 2016; Németh et al., 2017). Their popular appeal is substantial. Yet, we have argued here, this appeal can be enhanced further through a strategic alliance between geoheritage and cultural heritage researchers and managers. Several points stand out clearly. First and foremost, cultural heritage attractions tend to command greater attention and hence generate more income, jobs and attention. Cultural heritage professionals have developed, over the many years since the establishment of this field of research, numerous approaches to understanding and managing such sites and their attendant issues. Importantly, heritage is often contested and a robust handling of any heritage feature - geological or otherwise must be attuned to the potential for diverging viewpoints and value assignments. This is also at the core of dark heritage, where problematic or uncomfortable sites actually generate great visitor appeal and hence present themselves as particularly powerful places of engagement. Here, we have merely touched upon how issues of colonialism, slavery, vulnerability and resilience can be woven into the narratives about particular eruptions. Breaking down the increasingly artificial boundaries between natural/geological and cultural/historical heritage can be achieved through wider reading and publication - we have provided lists of the most important authors, articles and journals - and more interdisciplinary collaboration across the domains of geological and cultural heritage. Resulting outreach efforts can be brought into effect through, for instance, museums or local interest groups that provide uniquely suitable platforms for such engagements. Such interdisciplinarity would, we argue, be to the mutual benefit of both domains. 


\section{References}

Arnórsson, S., Thórhallsson, S. \& Stefánsson, A., 2015. Utilization of Geothermal Resources. In H. Sigurdsson, ed. The Encyclopedia of Volcanoes. Amsterdam: Academic Press, pp. 1235-1252.

Bachelor, B., 2014. Montserrat: a modern-day Pompeii in the Caribbean. Fox News. Available at: www.foxnews.com/travel/2014/02/20/montserrat-modern-day-pompeii-in-caribbean.html.

Bankoff, G., 2004. Time is of the Essence: Disasters, Vulnerability and History. International Journal of Mass Emergencies and Disasters, 22, pp.23-42.

Barclay, J. et al., 2015. Social Processes and Volcanic Risk Reduction. In H. Sigurdsson et al., eds. The Encyclopedia of Volcanoes. London: Academic Press, pp. 1203-1214.

Bastian, M., Heymann, S. \& Jacomy, M., 2009. Gephi: an open source software for exploring and manipulating networks. In International AAAI Conference on Weblogs and Social Media. San Jose.

Beard, M., 2008. Pompeii: The life of a Roman town, London: Profile.

Bitschene, P.R., 2015. Edutainment with basalt and volcanoes - the Rockeskyller Kopf example in the Westeifel Volcanic Field/Vulkaneifel European Geopark, Germany. Zeitschrift der Deutschen Gesellschaft für Geowissenschaften, 166(2), pp.187-193. Available at: http://openurl.ingenta.com/content/xref?genre=article\&issn=1860-

$1804 \&$ volume $=166 \&$ issue $=2 \&$ spage $=187$.

Bitschene, P.R. \& Schüller, A., 2011. Geo-education and geopark implementation in the Vulkaneifel European Geopark22nd ed., GSA FIeld Guide.

Blandin, P., 1992. La nature en Europe, Paris: Bordas.

Bolland, O.N., 1998. Creolisation and Creole Societies: a Cultural Nationalist View of Caribbean Social History. Caribbean Quarterly, 44(1), pp.1-32. Available at: http://www.jstor.org/stable/40654019\%5Cnhttp://www.jstor.org/stable/pdfplus/40654019.pdf?acceptTC=t rue.

Boyle, M., 2011. Metropolitan Anxieties: on the meaning of the Irish Catholic adventure in Scotland, London: Routledge. 
Brathwaite, K., 1971. Development of Creole Society in Jamaica 1770-1820, Oxford: Clarendon Press.

Briguglio, L., 1995. Small Island Developing States and Their Economic Vulnerabilities. World Development, 23,pp.1615-1632.

Brocx, M., 2007. Geoheritage - from global perspectives to local priniciples for conservation and planning, Welshpool.

Brocx, M. \& Semeniuk, V., 2007. Geoheritage and geoconservation - History, definition, scope and scale. Journal of the Royal Society of Western Australia, 90(2), pp.53-87.

Cameron, F. \& Neilson, B., 2015. Climate Change and Museum Futures Routledge., London: Routledge.

Cashman, K.V. \& Cronin, S.J., 2008. Welcoming a Monster to the World: Myths, Oral Tradition, and Modern Societal Response to Volcanic Disasters. Journal of Volcanology and Geothermal Research, 176(3), pp.407-418.

Cashman, K.V. \& Giordano, G., 2008. Volcanoes and Human History. Journal of Volcanology and Geothermal Research, 176(3), pp.325-329.

Chappin, E.J.L. \& Ligtvoet, A., 2014. Transition and transformation: A bibliometric analysis of two scientific networks researching socio-technical change. Renewable and Sustainable Energy Reviews, 30, pp.715723.

Charvériat, C., 2000. Natural Disasters in Latin America and the Caribbean: an Overiew of Risk,

Cherry, J.F. et al., 2012. The earliest phase of settlement in the Eastern Caribbean: new evidence from Montserrat. Antiquity, 86. Available at: http://www.antiquity.ac.uk/projgall/cherry333/.

Chester, D.K. et al., 2015. Human responses to the 1906 eruption of Vesuvius, southern Italy. Journal of Volcanology and Geothermal Research, 296, pp.1-18.

Corbera, E. et al., 2016. Patterns of authorship in the IPCC Working Group III report. Nature Climate Change, 6, pp.94-99. Available at: http://www.nature.com/nclimate/journal/v6/n1/abs/nclimate2782.html\#supplementary-information.

Cronin, S.J. \& Cashman, K.V., 2007. Volcanic Oral Traditions in Hazard Assessment and Mitigation. In J. Grattan \& R. Torrence, eds. Living Under The Shadow. Cultural Impacts of Volcanic Eruptions. London: 
UCL Press, pp. 175-202.

Culture, I.M. of, 2014. Culture in Italy 2014: Basic Figures, Rome.

Custodis, P.G., 1994. Evidence of Historical Stone Quarrying around Laacher-See. Denkmalpflege, 52, pp.149151.

Cutter, S.L. et al., 2008. A place-based model for understanding community resilience to natural disasters. Global Environmental Change, 18, pp.598-606.

Dann, G.M.S. \& Seaton, A.V., 2001. Slavery, contested heritage and thanatourism G. M. S. Dann \& A. V. Seaton, eds., New York: Haworth Hospitality Press.

Dávid, L., 2004. Active Tourism, Debrecen: Lifelong Learning.

Dehn, J. \& McNutt, S.R., 2015. Volcanic Materials in Commerce and Industry. In H. Sigurdsson, ed. The Encyclopedia of Volcanoes. Amsterdam: Academic Press, pp. 1285-1294.

Delmelle, P. et al., 2015. Volcanic soils. In H. Sigurdsson, ed. The Encyclopedia of Volcanoes. Amsterdam: Academic Press, pp. 1253-1264.

Ding, Y. et al., 2014. Writing information literacy assessment plans: A guide to best practice. Journal of the Association for Information Science and Technology, 3(2), pp.80-90.

Donovan, A., Eiser, J.R. \& Sparks, R.S.J., 2014. Scientists' views about lay perceptions of volcanic hazard and risk. Journal of Applied Volcanology, 3(1), p.15. Available at:

http://www.appliedvolc.com/content/3/1/15.

Donovan, A. \& Oppenheimer, C., 2016. Imagining the Unimaginable: Communicating Extreme Volcanic Risk. In K. Németh, ed. Advances in Volcanology. Berlin, Heidelberg: Springer Berlin Heidelberg, pp. 1-15.

Donovan, K., 2010. Doing Social Volcanology: Exploring Volcanic Culture in Indonesia. Area, 42(1), pp.117126.

Egghe, L., 2006. Theory and practice of the g-index. Scientometrics, 69, pp.131-152.

Erfurt-Cooper, P., 2010a. Geotourism in volcanic and geothermal environments: Playing with fire? Geoheritage, 3(3), pp.187-193. 
Erfurt-Cooper, P., 2010b. The Vulkaneifel in Germany. A Destination for Geotourism. In P. Erfurt-Cooper \& M. Cooper, eds. Volcano and Geothermal Tourism: Sustainable Geo-resources for Leisure and Recreation. London: Earthscan, pp. 281-285.

Erfurt-Cooper, P. \& Cooper, M., 2010. Volcano and Geothermal Tourism: Sustainable Geo-resources for Leisure and Recreation, London: Earthscan.

Erfurt-Cooper, P., Sigurdsson, H. \& Lopes, R.M.C., 2015. Volcanoes and Tourism. In H. Sigurdsson, ed. The Encyclopedia of Volcanoes. Amsterdam: Academic Press, pp. 1295-1311.

Everson, J.E., 2012. The melting pot of science and belief: studying Vesuvius in seventeenth-century Naples. Renaissance Studies, 26, pp.691-727.

Fanelli, D. \& Glänzel, W., 2013. Bibliometric Evidence for a Hierarchy of the Sciences. PLoS ONE, 8.

Fergus, H.A., 1996. Gallery Montserrat: some prominent people in our history, Kingston, Jamaica: Canoe Press.

Fernández, J., Moshenska, G. \& Iriarte, E., 2017. Archaeology and Climate Change: Evidence of a Flash-flood During the LIA in Asturias (NW Spain) and its Social Consequences. Environmental Archaeology, pp.111.

Finneran, N., 2013. This Islande is inhabited with all sortes': The archaeology of creolisation in Speightstown, Barbados, and Beyond, AD 1650-1900. Antiquaries Journal,93(c), pp.319-351.

Foley, M. \& Lennon, J.J., 1996. JFK and dark tourism: A fascination with assassination. International Journal of Heritage Studies, 2, pp.198-211.

García-Acosta, V., 2002. Historical disaster research. In S. M. Hoffman \& A. Oliver-Smith, eds. Catastrophe and Culture: The Anthropology of Disaster. Santa Fe, NM: School of American Research Press, pp. 4966.

Gibson, N. et al., 1994. A floristic survey of the southern Swan Coastal Plain,

Hambrecht, G. \& Rockman, M., 2017. International Approaches to Climate Change and Cultural Heritage. American Antiquity, 82(4), pp.627-641.

Harzing, A.W., 2007. Publish or Perish. Available at: http://www.harzing.com/pop.htm. 
Hoffmann, K. \& Doucette, L., 2012. A Review of Citation Analysis Methodologies for Collection Management. College \& Research Libraries, 73(4), pp.321-335. Available at: http://crl.acrl.org/index.php/crl/article/view/16239.

Hølleland, H., Skrede, J. \& Holmgaard, S.B., 2017. Cultural Heritage and Ecosystem Services: ALiterature Review. Conservation and Management of Archaeological Sites, 19(3), pp.210-237. Available at: http://doi.org/10.1080/13505033.2017.1342069.

Holmberg, K., 2013. An Inheritance of Loss: Archaeology's Imagination of Disaster. In M. I. J. Davies \& F. N. M'Mbogori, eds. Humans and the Environment: New Archaeological Perspectives for the Twenty-First Century. Oxford: Oxford University Press, pp. 197-209.

Hooper, G. \& Lennon, J.J., 2017. Dark tourism: practice and interpretation G. Hooper \& J. J. Lennon, eds., London: Routledge.

Hull, D.L., 1988. Science as a process, Chicago: University of Chicago Press.

Hulme, M., 2011. Meet the Humanities. Nature Climate Change, 1, pp.177-179.

IAPG, 2012. Constitution of the International Association for Promoting Geoethics. Available at: http://www.iapg.geoethics.org/img/IAPG_Constitution.pdf.

Istat, 2016. Annon 2015. I Musei, Le aree archeologiche e i monumenti in Italia,

Jackson, R., Dugmore, A.J. \& Riede, F., 2018. Rediscovering lessons of adaptation from the past. Global Environmental Change, 52, pp.58-65.

Jackson, R., Dugmore, A.J. \& Riede, F., 2017. Towards a new social contract for archaeology and climate change adaptation. Archaeological Review from Cambridge, 32, pp.197-221.

James, P., Chester, D.K. \& Duncan, A.M., 2000. Volcanic soils: their nature and archaeological significance. In W. J. McGuire et al., eds. The Archaeology of Geological Catastrophes. London: Geological Society Special Publication No. 171, pp. 317-338.

Janssens, C.B. \& O’Keefe, T., 2010. St. Pierre, Martinique: The Pompeii of the Caribbean. Available at: https://allthingscruise.com/st-pierre-martinique-the-pompeii-of-the-caribbean/ [Accessed May 29, 2018 ].

Jones, T. \& Ohsawa, T., 2016. Monitoring Nature-Based Tourism Trends in Japan's National Parks: Mixed 
Messages From Domestic and Inbound Visitors. Parks, 22(1), pp.25-36. Available at:

10.2305IUCN.CH_.2016.PARKS-22-1TJ.en_.pdf.

Kelman, I. \& Mather, T.A., 2008. Living with Volcanoes: The Sustainable Livelihoods Approach for VolcanoRelated Opportunities. Journal of Volcanology and Geothermal Research, 172(3-4), pp.189-198.

Kostoff, R.N., 1998. The use and misuse of citation analysis in research evaluation. Scientometrics, 43, pp.2743.

Kozák, J. \& Cermák, V., 2010. The Illustrated History of Natural Disasters, Amsterdam: Springer.

Kremer, B.P., 1995. Laacher See. Landschaft, Natur, Kunst, Kultur, Köln: Wienand Verlag.

Kulcsar, E. \& Simon, R.Z., 2015. The magic of dark tourism. Management \& Marketing Journal, 13(1), pp.124-136.

Kverndokk, K., 2015. Naturkatastrofer. En kulturhistorie, Oslo: Scandinavia Academic Press.

Lalubie, G., 2013. Volcanic hydro-geomorphology of the montagne pelee and the rediscovery of an ancestral problematic (Carib, Kalinago) in the Lesser Antilles. Bulletin de la Societe Geologique de France, 184(12), pp.129-135.

Lawani, S.M., 1977. Citation analysis and the quality of scientific productivity. BioScience, 27, pp.26-31.

Leder, J. et al., 2017. Loss of residential buildings in the event of a re-awakening of the Laacher See Volcano (Germany). Journal of Volcanology and Geothermal Research, 337, pp.111-123.

Lewis, D.M. \& Alpi, K.M., 2017. Bibliometric Network Analysis and Visualization for Serials Librarians: An Introduction to Sci2. Serials Review, 43, pp.239-245.

Lewis, S.L. \& Maslin, M.A., 2015. Defining the Anthropocene. Nature, 519, pp.171-180.

Lowenthal, D., 2005. Natural and cultural heritage. International Journal of Heritage Studies, 11(1), pp.81-92.

De Lucia, M., 2014. 'When Will Vesuvius Erupt?” Why research institutes must maintain a dialogue with the public in a high-risk volcanic area: the Vesuvius Museum Observatory. In S. Peppoloni \& M. Wyss, eds. Geoethics. Oxford: Elsevier, pp. 335-349. Available at: http://dx.doi.org/10.1016/B978-0-12-7999357.00027-7. 
McAtackney, L., 2013. Dealing with Difficult Pasts: The Dark Heritage of Political Prisons in Transitional Northern Ireland and South Africa. Prison Service Journal, 210, pp.17-24.

McAtackney, L., Ryzewski, K. \& Cherry, J.F., 2014. Contemporary Irish identity on the Emerald Isle of the Caribbean. In D. S. Nititham \& R. Boyd, eds. Heritage, Diaspora and the Consumption of Culture. London: Routledge, pp. 113-134.

McBriar, M., 1995. Forward. In E. B. Joyce, ed. A report preparedfor the Australian Heritage Commission. Sydney: Committee for the Geological Heritage of the Geological Society of Australia Inc.

McGrattan, C., 2010. The Northern Ireland Conflict. In C. McGrattan, ed. Northern Ireland 1968-2008. London: Palgrave Macmillian, pp. 7-33.

Mercer, J. et al., 2012. Culture and disaster risk reduction: lessons and opportunities. Environmental Hazards, 11, pp.74-95.

Millennium Ecosystem Assessment, 2003. Ecosystems and human well-being: a frameworkfor assessment, Washington D.C.: Island Press.

Millennium Ecosystem Assessment, 2005. Guide to the Millennium Assessment Reports. Available at: https://www.millenniumassessment.org/en/index.html [Accessed May 22, 2018].

Mlambo, A.S., 2006. Western social sciences and Africa: the domination and marginalisation of a Continent. African Sociological Review, 10, pp.161-179.

Montero, C.G., 2011. On tourism and the constructions of 'Paradise Islands' in Central America and the Caribbean. Bulletin of Latin American Research, 30, pp.21-34.

Moshenska, G. \& Dhanjal, S., 2011. Community Archaeology: Themes, Methods and Practices, Oxford: Oxbow.

Moshenska, G., Dhanjal, S. \& Cooper, D., 2011. Building Sustainability in Community Archaeology: the Hendon School Archaeology Project. Archaeology International, 13, pp.94-100.

Mowatt, R.A. \& Chancellor, C.H., 2011. Visiting death and life. Dark tourism and slave castles. Annals of Tourism Research,38(4), pp.1410-1434. Available at: http://dx.doi.org/10.1016/j.annals.2011.03.012.

Németh, K. et al., 2017. Volcanic Geoheritage. Geoheritage, 9, pp.251-254. 
Németh, K. \& Cronin, S.J., 2009. Volcanic structures and oral traditions of volcanism of Western Samoa (SW Pacific) and their implications for hazard education. Journal of Volcanology and Geothermal Research, 186, pp.223-237.

Neuberg, J., 2014. Thoughts on ethics in volcanic hazard research. In S. Peppoloni \& M. Wyss, eds. Geoethics. Oxford: Elsevier, pp. 305-312.

Nicolaisen, J., 2007. Citation analysis. Annual Review of Information Science and Technology, 41, pp.609-641.

Nightingale, J.M. \& Marshall, G., 2013. Citation analysis as a measure of article quality, journal influence and individual researcher performance. Nurse Education in Practice, 13(5), pp.429-436. Available at: http://dx.doi.org/10.1016/j.nepr.2013.02.005.

O’Keefe, P., Westgate, K. \& Wisner, B., 1976. Taking the naturalness out of natural disasters. Nature, 260, pp.566-567.

Park, C. \& Schmincke, H.U., 2009. Apokalypse im Rheintal Spektrum der Wissenschaften,

Parkash, S., 2012. Ethics in disaster management. Annals of Geophysics, 55.

Peppoloni, S. \& Di Capua, G., 2012. Geoethics and geological culture: awareness, responsibility and challenges. Annual Geophysics, 55, pp.335-341.

Pomeroy, A.J., 2008. Then it was Destroyed by the Volcano: The ancient world in film and on television, London: Duckworth.

Pyle, D.M., 2017. Volcanoes: Encounters through the Ages, Oxford: Bodleian Library.

Radev, D.R. et al., 2015. A bibliometric and network analysis of the field of computational linguistics. Journal of the Association for Information Science and Technology, 67, pp.683-706.

Rees, M., 2017. Museums as catalysts for change. Nature Climate Change, 7, pp.166-167.

Reid, B.A., 2009. Myths and realities of Caribbean history, Tuscaloosa, Alabama: University of Alabama Press.

Riede, F. et al., 2011. A Laacher See-eruption supplement to Tephrabase: Investigating distal tephra fallout dynamics. Quaternary International, 246, pp.134-144.

Riede, F., 2016. Changes in mid- and far-field human landscape use following the Laacher See eruption (c. 
13,000 BP). Quaternary International, 394, pp.37-50.

Riede, F., 2018. Doing palaeo-social volcanology: Developing a framework for systematically investigating the impacts of past volcanic eruptions on human societies using archaeological datasets. Quaternary International.

Riede, F., Sørensen, A.H., et al., 2016. Learning from the past - teaching past climate change and catastrophes as windows onto vulnerability and resilience. In S. Siperstein, S. Lemenager, \& S. Hall, eds. Teaching Climate Change in the Humanities. New York: Routledge, pp. 126-135.

Riede, F., 2017a. Past-Forwarding Ancient Calamities. Pathways for Making Archaeology Relevant in Disaster Risk Reduction. Humanities, 6, p.79.

Riede, F., 2017b. Splendid isolation. The eruption of the Laacher See volcano and southern Scandinavian Late Glacial hunter-gatherers, Aarhus: Aarhus University Press.

Riede, F., 2008. The Laacher See-Eruption (12,920 BP) and Material Culture Change at the End of the Allerød in Northern Europe. Journal of Archaeological Science, 35(3), pp.591-599.

Riede, F., Andersen, P. \& Price, N., 2016. Does environmental archaeology need an ethical promise? World Archaeology, 48(4), pp.466-481. Available at: https://doi.org/10.1080/00438243.2016.1192483.

Robb, E., 2009. Violence and recreation: vacationing in the realm of dark tourism. Anthropology and Humanism, 34, pp.51-60.

Roberts-Wray, K., 1966. Commonwealth and colonial law, London: Stevens.

Robertson, R., 1995. An Assessment of the Risk From Future Eruptions of the Soufriere Volcano of St. Vincent, West Indies. Natural Hazards, 11(2), pp.163-191.

Robertson, R., 2005. St. Vincent. In J. M. Lindsay et al., eds. Volcanic Hazard Atlas of the Lesser Antilles. Trinidad and Tobago: Seismic Research Unit, The University of the West Indies, pp. 240-261.

Rockman, M., 2015. An NPS Framework for Addressing Climate Change with Cultural Resources. The George Wright Forum, 32, pp.37-50.

Russell, K.P., 2015. Visualising the historic landscape of Montserrat: social justice through community mapping in a post-colonial environment. University of Tennessee. 
Ryzewski, K. \& Cherry, J.F., 2012. Communities and archaeology under the Soufrière Hills Volcano on Montserrat, West Indies. Journal of Field Archaeology, 37(4), pp.316-327.

Sarli, C.C., Dubinsky, E.K. \& Holmes, K.L., 2010. Beyond citation analysis: a model for assessment of research impact. Journal of the Medical Library Association : JMLA, 98(1), pp.17-23. Available at: http://www.ncbi.nlm.nih.gov/pmc/articles/PMC2801963/.

Scandone, R., Bartolini, S. \& Martí, J., 2015. A scale for ranking volcanoes by risk. Bulletin of Volcanology, 78, pp.1-8.

Schmincke, H.U., 2006. Environmental impacts of the Lateglacial eruption of the Laacher See Volcano, 12.900 cal BP. In W. von Koenigswald \& T. Litt, eds. 150 years of Neanderthal Discoveries. Bonn: Terra Nostra, pp. 149-153.

Schmincke, H.U., Park, C. \& Harms, E., 1999. Evolution and environmental impacts of the eruption of Laacher See Volcano (Germany) 12,900 a BP. Quaternary International, 61, pp.61-72.

Seglen, P.O., 1997. Why the impact factor of journals should not be used for evaluating research. British Medical Journal, 314, pp.498-502.

Shackley, M., 2001. Potential futures for Robben Island: shrine, museum or theme park? International Journal of Heritage Studies, 7, pp.355-363.

Shepherd, V. \& Richards, G., 2002. Introduction. In Questioning Creole: creolisation discourses in Caribbean culture. Kingston, Jamaica: Ian Randle, pp. xi-xxvii.

Sidiropoulos, A., Katsaros, D. \& Manolopoulos, Y., 2006. Generalised h-index for disclosing latent facts in citatiin networks., 1. Available at: https://arxiv.org/abs/cs/0607066.

Sigurdsson, H., 2015. Volcanoes in Art. In H. Sigurdsson, ed. Encyclopedia of Volcanoes. Amsterdam: Academic Press, pp. 1321-1343.

Skinner, J., 2018. Plymouth, Montserrat: apocalyptic dark tourism at the Pompeii of the Caribbean. International Journal of Tourism Cities, 4, pp.123-139. Available at: http://www.emeraldinsight.com/doi/10.1108/IJTC-08-2017-0040.

Smith, A.L. et al., 2007. Prehistoric Stratigraphy of the Soufrière Hills - South Soufrière Hills Volcanic Complex, Montserrat, West Indies. The Journal of Geology, 115(1), pp.115-127. 
Solana, M.C., Kilburn, C. \& Rolandi, G., 2008. Communicating eruption and hazard forecasts on Vesuvius, Southern Italy. Journal of Volcanology and Geothermal Research, 172, pp.308-314.

Spence, R. et al., 2007. Residential building and occupant vulnerability to pyroclastic density currents in explosive eruptions. Natural Hazards and Earth System Science, 7, pp.219-230.

Strange, C. \& Kempa, M., 2003. Shades of dark tourism: Alcatraz and Robben Island. Annals of Tourism Research,30(2), pp.386-405.

Stueve, A., Cook, S.D. \& Drew, D., 2002. The geotourism study: phase I executive summary, Washington.

SVG Tourism Authority, 2009. St. Vincent and the Grenadines, Eco-adventures: Hiking. Available at: http://discoversvg.com/index.php/en/whattodo/eco-adventures/hiking [Accessed May 30, 2018].

Sword-Daniels, V. et al., 2014. Consequences of Long-Term Volcanic Activity for Essential Services in Montserrat: Challenges, Adaptations and Resilience. In G. Wadge, R. Robertson, \& B. Voight, eds. The Eruption of Soufrière Hills Volcano, Montserrat From 2000 to 2010. London: Geological Society, pp. 471-488. Available at: http://mem.lyellcollection.org/cgi/doi/10.1144/M39.26.

Thomas, S., Seitsonen, O. \& Herva, V.P., 2016. Nazi memorabilia, dark heritage and treasure hunting as "alternative" tourism: Understanding the fascination with the material remains of World War II in Northern Finland. Journal of Field Archaeology, 41, pp.331-343.

Thorarinsson, S., 1979. On the Damage Caused by Volcanic Eruptions with Special Reference to Tephra and Gases. In P. Sheets \& D. K. Grayson, eds. Volcanic Activity and Human Ecology. New York: Academic Press, pp. 125-160.

Tunbridge, J.E. \& Ashworth, G.J., 2017. Is all tourism dark? In G. Hooper \& J. J. Lennon, eds. Dark tourism: practice and interpretation. London: Routledge, pp. 12-25.

Ugolini, F.C. \& Zasoski, R.J., 1979. Soils Derived from Tephra. In P. Sheets \& D. K. Grayson, eds. Volcanic activity and human ecology. Academic Press, pp. 83-124.

UNESCO, 2018. Rock art of St. Vincent and the Grenadines. Available at: https://whc.unesco.org/en/tentativelists/5749/ [Accessed May 29, 2018].

Wade, N., 1975. Citation analysis: a new tool for science administrators. Science, 188, pp.429-432. 
Whitehouse, G.H., 2001. Ciation rates and impact factors: should they matter? British Journal of Radiology, 74, pp. $1-3$.

Withers, P.C.\& Horwitz, P., 1996. ymposium on the design of reserves for Nature Conservation in southwestern Australia. Journal of the Royal Society of Western Australia, 79, pp.225-304.

Wolf, E.R., 1990. Europe and the People without History 2nd ed., Berkeley, CA: University of California Press.

Wyatt, B. \& Moss, D., 1990. CORINE biotopes: the design, compilation, and use of an inventory of sites of major importance for nature conservation in the European community, Luxembourg: The Commission of the European Communities.

Zuccaro, G. et al., 2008. Impact of explosive eruption scenarios at Vesuvius. Journal of Volcanology and Geothermal Research, 178, pp.416-453. 
Click here to download Figure Scarett \& Riede_Geoheritage_Fig1.png $\underline{\underline{\Perp}}$

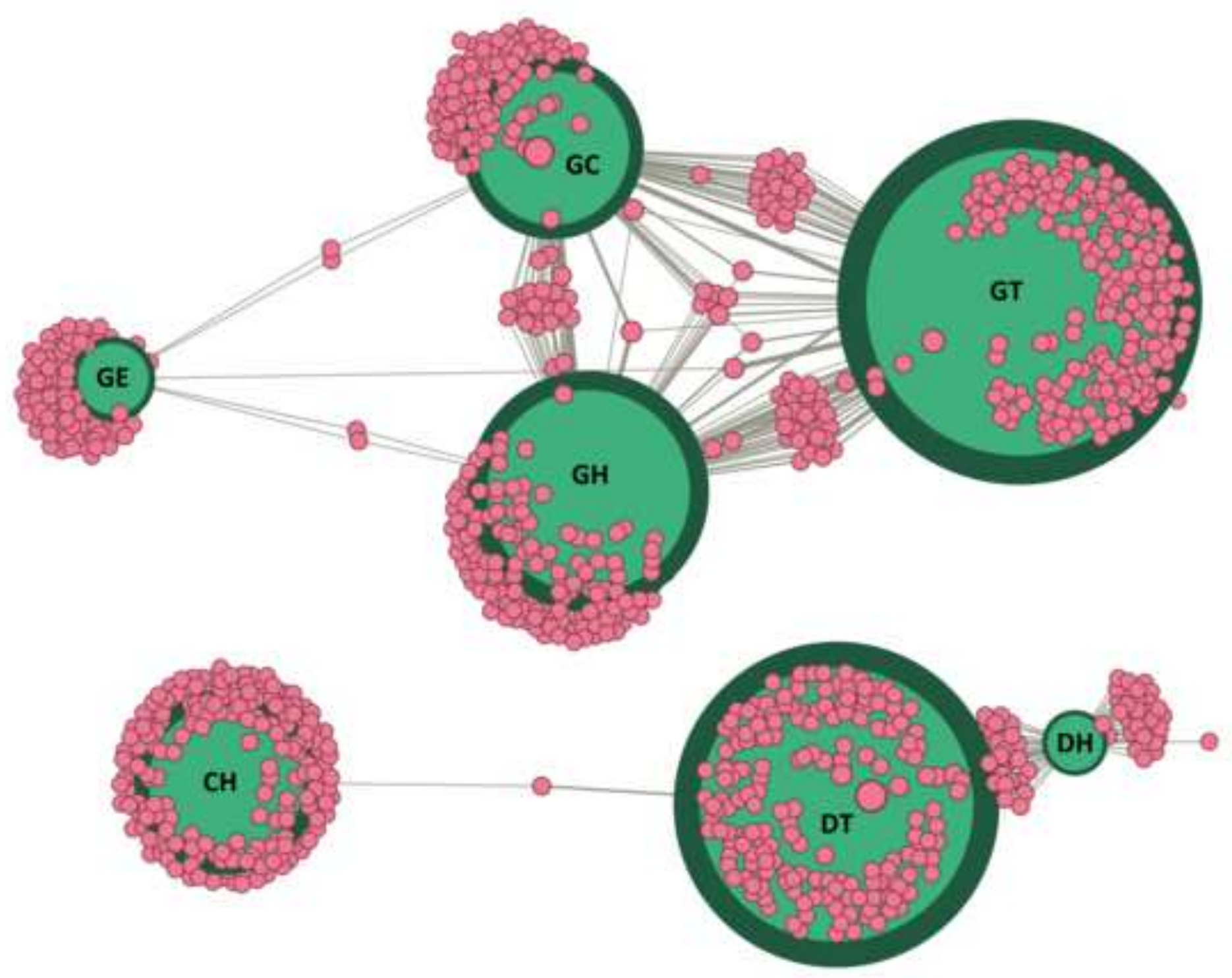


Click here to download Figure Scarlett \& Riede_Geoheritage_Fig2.png

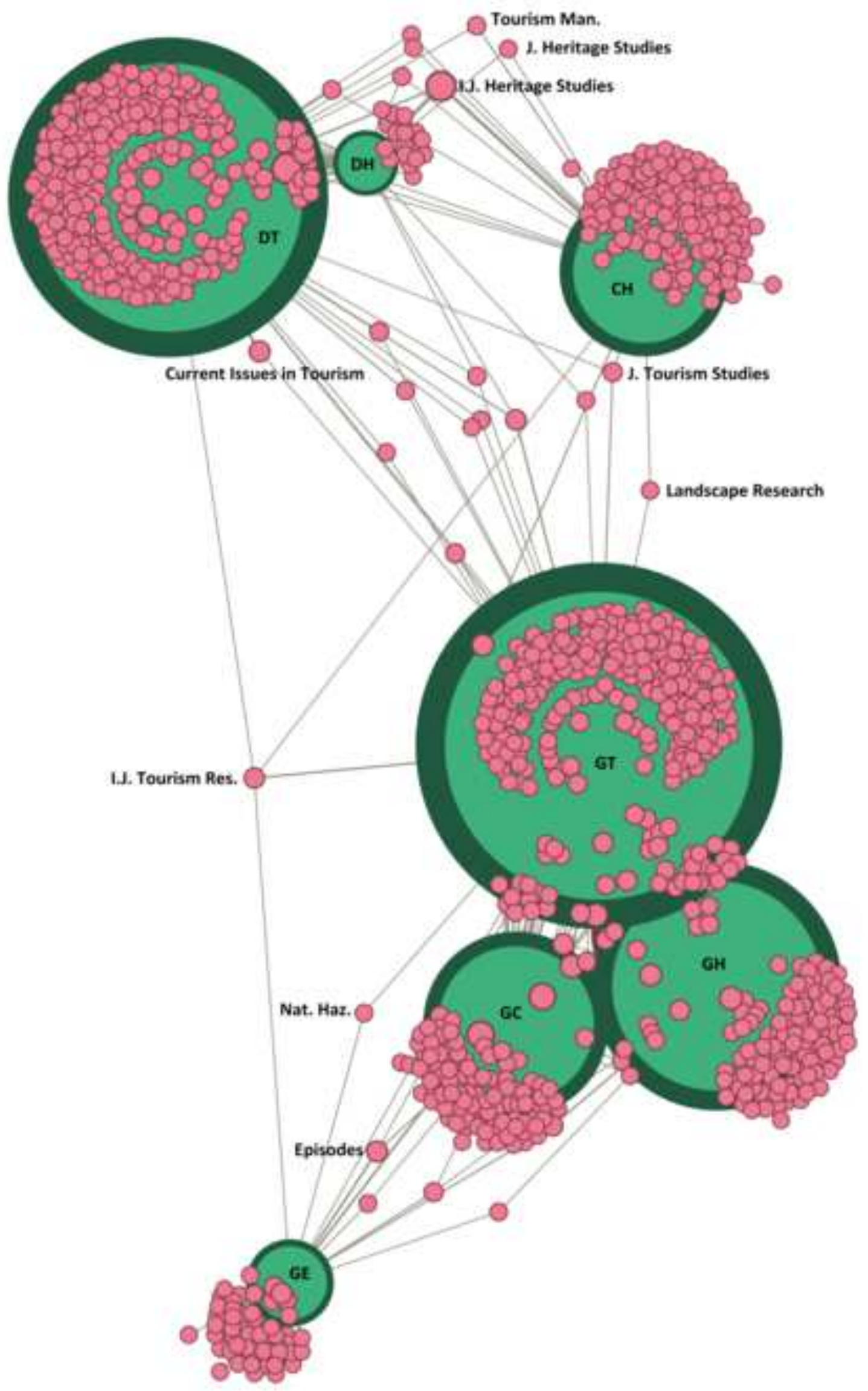




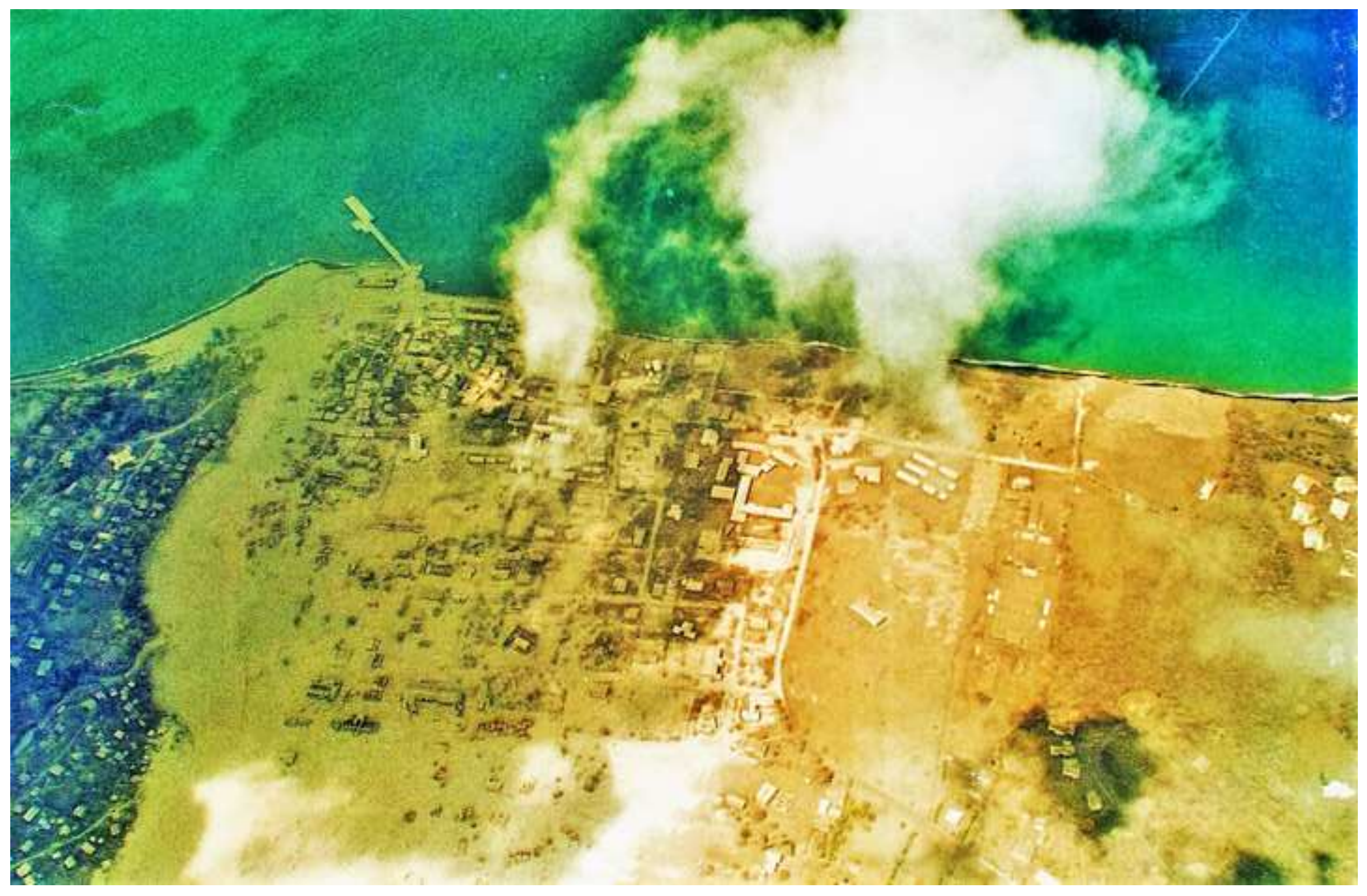




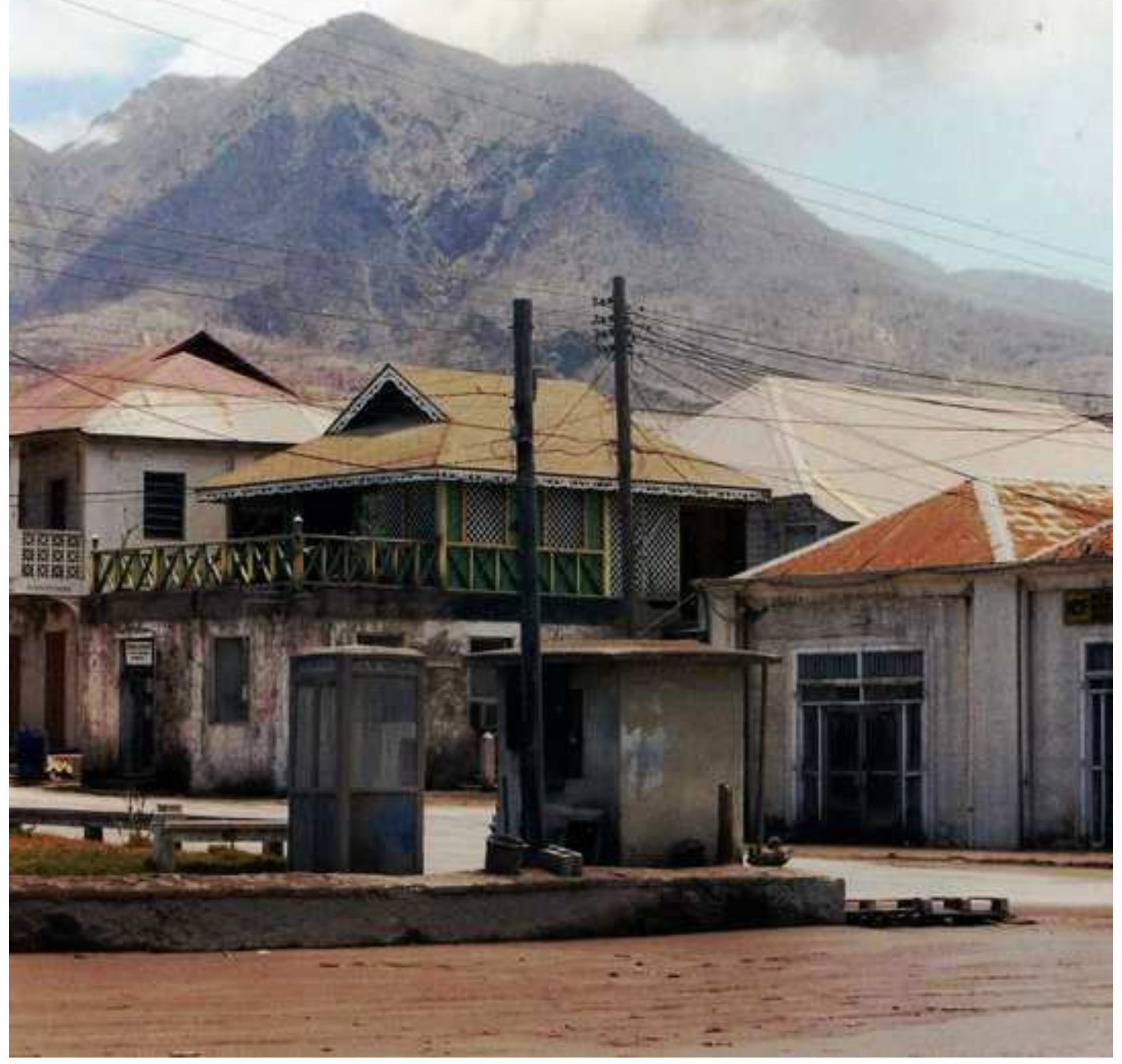




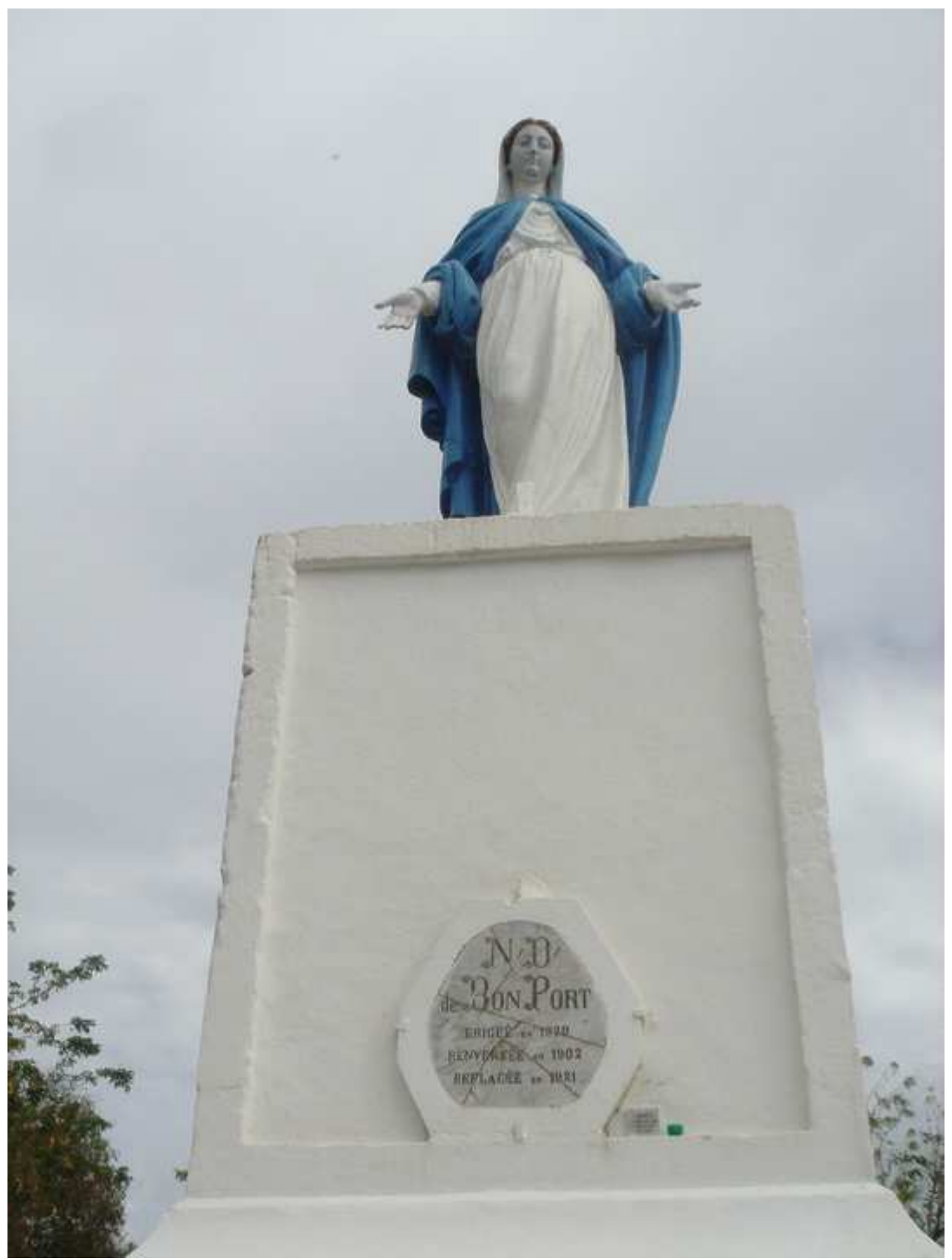




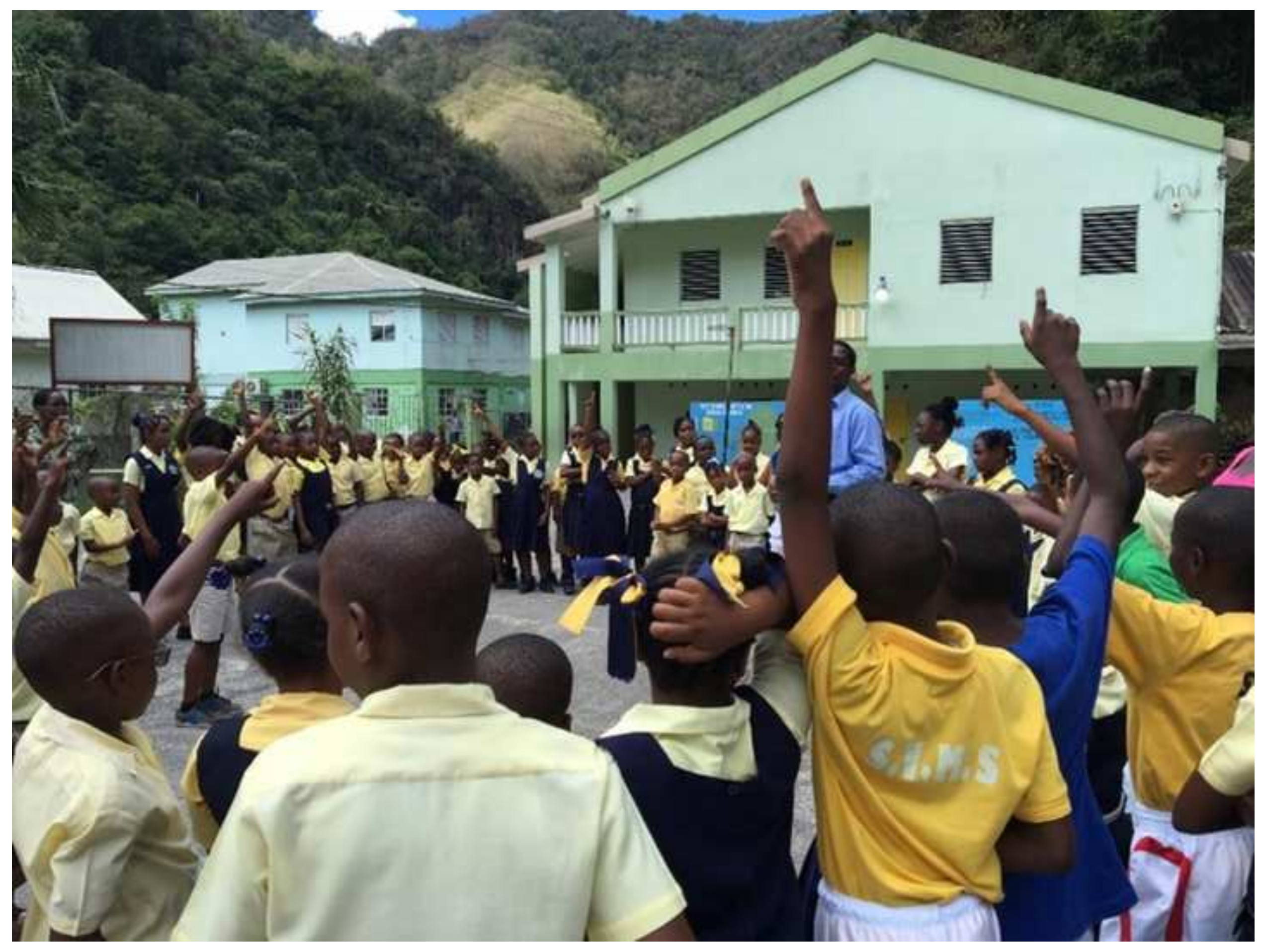




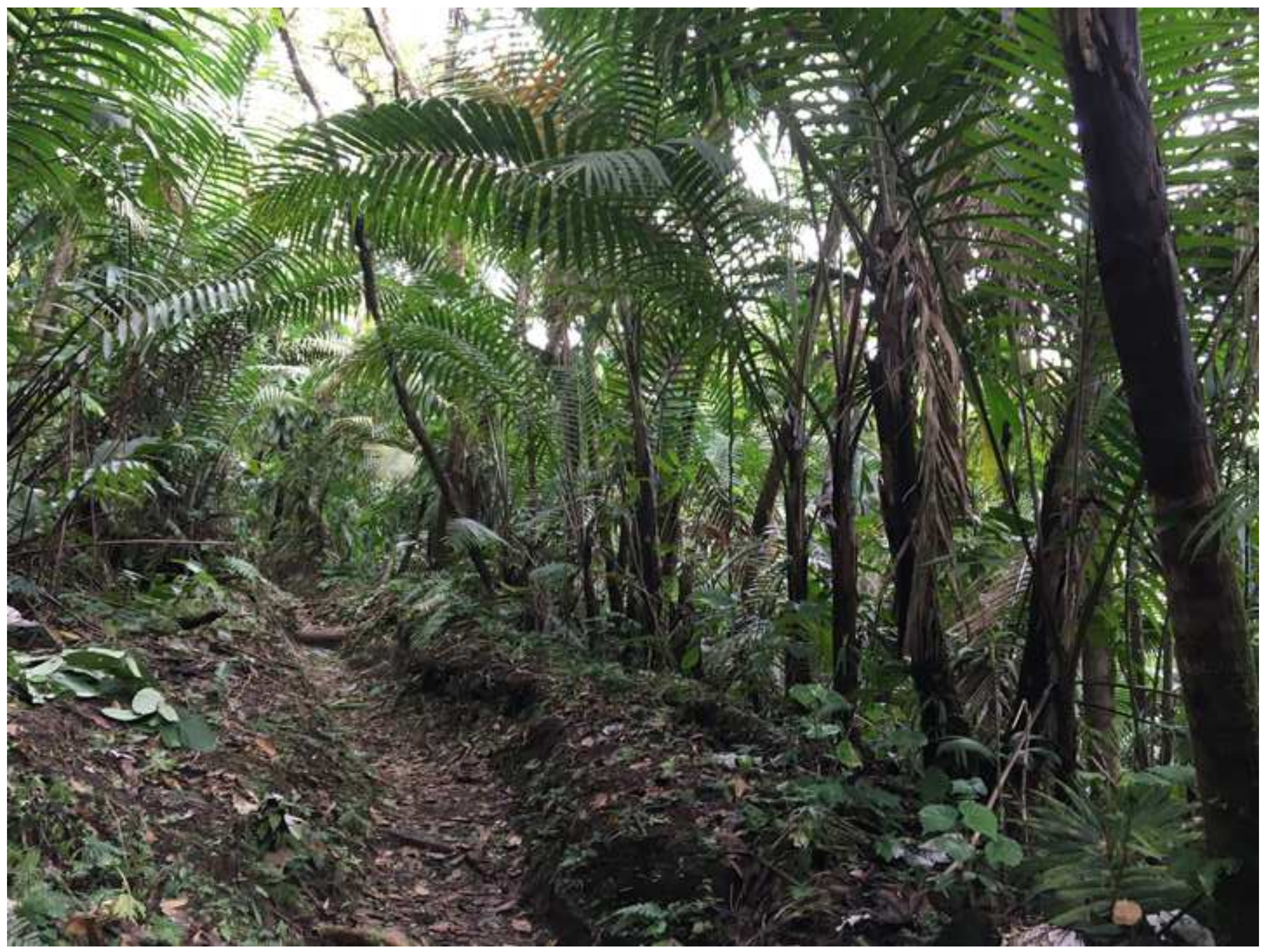




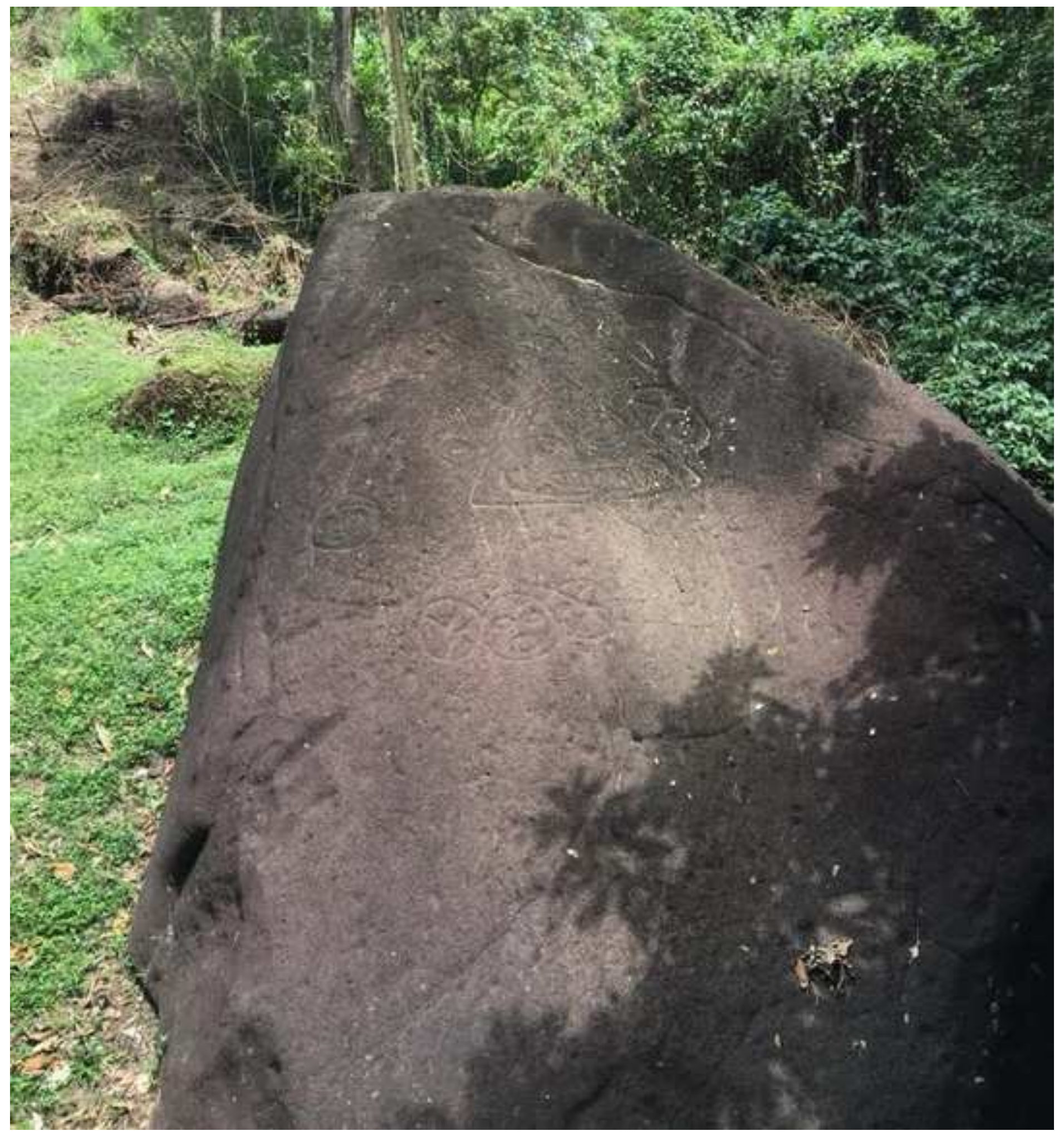



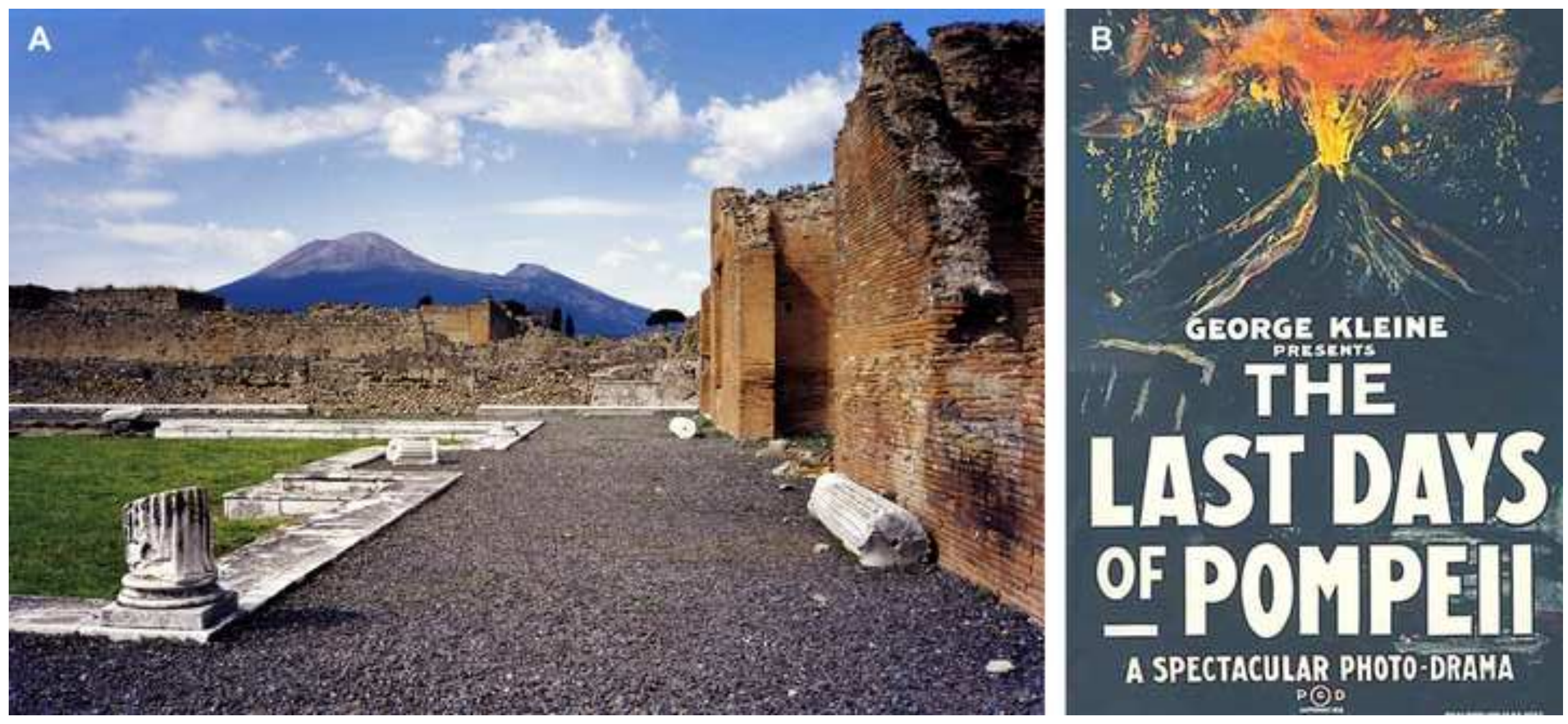


\section{Click here to download Figure Scarlett \& Riede_Geoheritage_Fig8 $\stackrel{\underline{ }}{ }$}

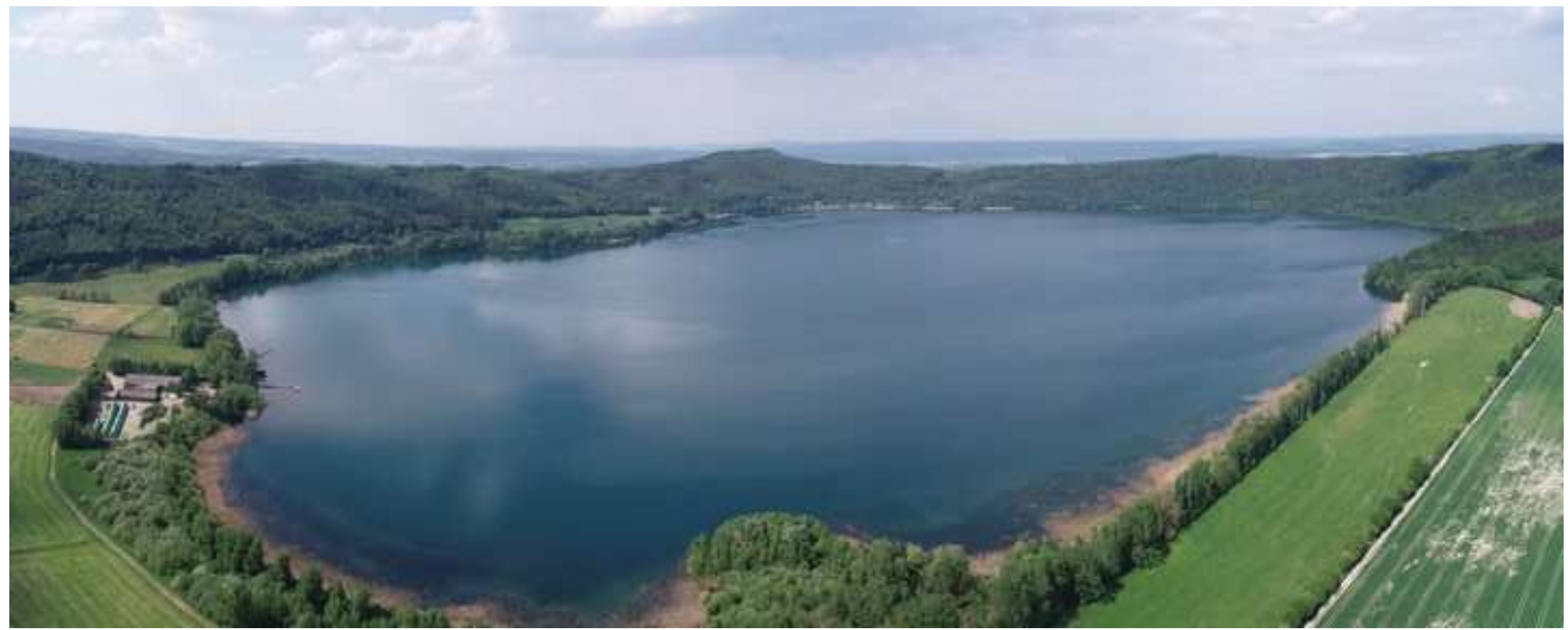



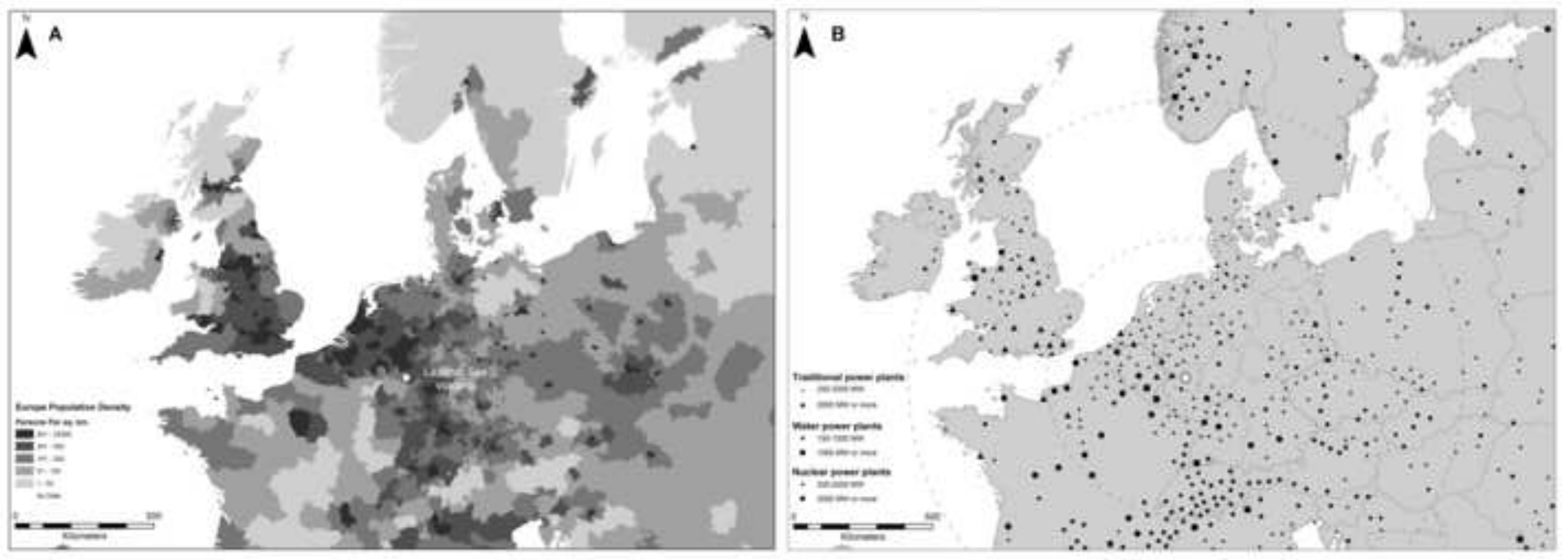


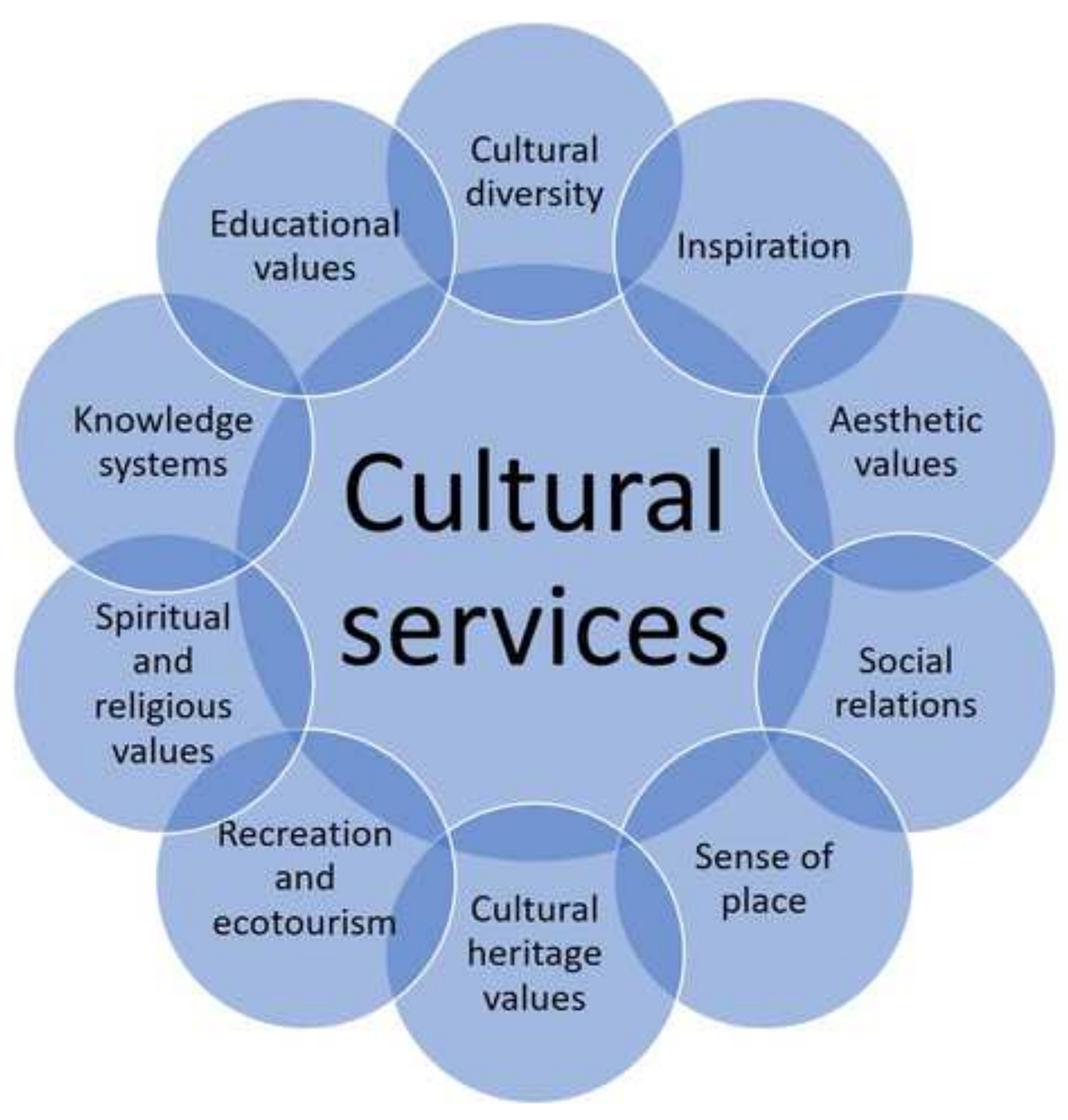

